\title{
Amik Ovası'nın Tarım (Agro) Turizmi Potansiyelinin Coğrafi Yaklaşımla İncelenmesi
}

Investigation of Agriculture (Agro) Tourism Potential of Amik Plain with Geographical Perspective

\author{
Emre ÖZŞAHiN*, Çağlar Kıvanç KAYMAZ** \\ **Yrd. Doç. Dr., Namık Kemal Üniversitesi, Fen-Edebiyat Fakültesi, Coğrafya Bölümü, 59030, Süleymanpaşa, Tekirdă̆ \\ E-posta:eozsahin@nku.edu.tr \\ *Arş. Gör., Atatürk Üniversitesi, Edebiyat Fakültesi, Coğrafya Bölümü, 25000, Merkez, Erzurum. \\ E-posta: ckkaymaz@gmail.com
}

\section{MAKALE BILGILERI}

Makale işlem bilgileri:

Gönderilme tarihi: 13 Ekim 2013

Birinci değerlendirme: 24 Aralık 2013

İkinci değerlendirme: 10 Ocak 2014

Kabul: 27 Şubat 2014

\section{Anahtar sözcükler:}

Turizm coğrafyası,

Tartm coğrafyası,

Tarim turizmi,

Amik ovası, Hatay.

\section{ARTICLE INFO}

Article history:

Submitted: 13 October 2013

Resubmitted: 24 December 2013

Resubmitted: 10 January 2014

Accepted: 27 February 2014

\section{Key words:}

Tourism geography,

Agricultural geography,

Agricultural Tourism,

Amik Plain, Hatay.

\section{ÖZ}

Dünyada gün geçtikçe önem kazanan turizm etkinliklerinden biri de tarım (agro) turizmidir. Son zamanlarda bu turizm, başta gelişmekte olan ülkelerde hem kırsal kalkınmanın sağlanabilmesi hem de biyolojik çeşitlilik ve ekosistemi korumaya katkıda bulunmak amacıyla desteklenmekte ve teşvik edilmektedir. Bu çalışmada Amik Ovası'nın tarım turizmi potansiyelinin coğrafi açıdan incelenmesi amaçlanmıștır. Bu amaçla ovanın tarım turizmine uygun potansiyel alanları tespit edilmiş ve tarım turizmi potansiyeli değerlendirilmiştir. Amik Ovası için tarım turizmi kapsamında öncü bir çalışma olan bu yayın, daha çok tanıtım ve planlamalar için önem taşımaktadır. Calıșmanın tematik haritaları, ilgili alanyazın, çeșitli haritalar ve veriler kullanılarak Çok Kriterli Karar Verme Yöntemi'ne göre Coğrafi Bilgi Sistemleri (CBS) teknikleriyle ișlenerek oluşturulmuştur. Elde edilen veriler arazi çalışmalarıyla kontrol edilmiş ve SWOT analiziyle tutarılıkları ölçülmüştür. Sonuçta Amik Ovası'nın sahip olduğu doğal ortam özelliklerinin çok yüksek bir tarım turizmi potansiyeli barındırdığı anlaşılmıştır. Çalışmada yapılan analizler sonucunda ovanın \%99'unun tarım turizmine en uygun ve uygun alanlardan oluștuğu tespit edilmiștir. Ancak ovada tarım turizmiyle ilgili herhangi bir gelişme yoktur. Bu bağlamda öncelikli olarak ovanın tarım turizmi planlaması yapılmalıdır. Ayrıca yapılacak çalışmalarda yerel halkın da katıımı sağlanmalı, eğitimler verilmelidir.

\begin{abstract}
One of tourism activities gaining importance day by day in the world is agriculture (agro) tourism. Recently, this tourism, in order to contribute to ensuring rural development, as well as protecting of biodiversity and ecosystem is supported and encouraged particularly in developing countries. In this study, it is aimed to valuation of agro tourism potential of Amik Plain in geographical terms. The article, which is a pioneering study for the scope of agro tourism of Amik Plain, is preferably important for the promotion and planning. Thematic maps of the study are created by Geographic Information Systems (GIS) techniques according to Method of Multi-criteria Decision Making in terms of subject matter and scope the relevant literature addition to using a variety of maps and data. Obtained data's were tested by land studies and consistencies were measured by SWOT analysis. Eventually, it appears that characteristics of the natural environment of the Amik Plain has a very high potential for agro tourism. In the study, it has been identified to $99 \%$ of The Plain was formed from the most appropriate and appropriate areas for agro tourism, as a result of the analysis. However, there has not been any activity about the scope of related tourism on the plain. In this context, agro tourism planning of plain should be made, primarily. Furthermore, for further studies, encouraging and informative meetings should be done with ensuring the participation of the local people.
\end{abstract}

\section{Giriş}

Son yıllarda dünyanın en önde gelen ekonomik sektörlerinden biri haline gelen turizme olan talep her geçen gün artmaktadır (Soykan 2000; Çıkın vd. 2009). Bu artış; turizmin mekânsal yayılış özellikleri, mekân üzerindeki etkileri, ortaya çıkan turistik alan ve bölgelerin tespiti ve gruplandırılması, arazinin kullanım kapasitesinin belirlenmesi için ölçütlerin araştırılması ve korunması ile ilgili ön- lemlerin alınmasını gerekli kılmaktadır (Kozak vd. 2001). Bu durum turizm coğrafyasının önemini arttırmaktadır. Turizm coğrafyasının turizm için en önde gelen işlevinden biri de planlama çalışmalarına yardımcı olmaktır. Bilhassa turistik yörelerin belirlenmesinde ve öncelikli alanların seçimi ile turizm türlerinin planlanmasında turizm coğrafyasından en etkin bir şekilde yararlanılmaktadır (Soykan 2000). 
Günümüzde uluslararası turizm hareketlerindeki artışa bağlı olarak meydana gelen talepler, turizmin yanında tarım sektörünün gelişmesine de neden olmuştur (Olalı ve Timur 1988; Türkben vd. 2012). Bu durum, çevrenin doğal ve beşeri koşullarıyla tarımsal etkinlikler arasındaki ilişki kuran (Doğanay ve Coşkun, 2012) tarım coğrafyasını da etkilemiş ve tarım turizminin ön plana çıkmasını da beraberinde getirmiştir (Kiper ve Arslan 2007; Çıkın vd. 2009; Özdede 2012). Böylece bu turizm türü ulusal ve uluslararası girişimlerle içeriği zenginleştirilerek dünyanın en hızlı büyüyen sektörlerinden biri olmuştur (Wacher 2006). Kırsal turizmin bir alt dalı olarak ortaya çıkan tarım turizmi (Nilsson 2002), tarımsal konularla alakalı her türlü bilgi ve pratik uygulamalarla birlikte turistlere gezme, öğrenme ve keşfetmenin zevkine varabilecekleri çeşitli kırsal aktiviteler sunar (Woo ve Yeon 2006). Bu bakımdan genellikle kırsal çevreye bağlı olan kirsal turizmin (Soykan 1999; 2002; 2003a) aksine, tarım turizmi ekili alana ve çiftçiye bağl1dır. Burada asıl önemli olan, tarımsal alanlardaki konaklama ve yeme-içme imkânlarının aynı anda hem tarım hem de turizm amaçlı kullanılabilmesidir (Nilsson 2002; Özdede 2012).

Dünyada tarım turizmi giderek yaygınlaşmakta ve bu durum planlı-projeli çalışmaların yapılmasını gerekli kılmaktadır (Ak 2006; Türkben vd. 2012). Ancak ne yazık ki Türkiye'nin Dünya coğrafyasında birçok ülkeye göre kültürel ve doğal kaynaklarının daha zengin olmasına rağmen, tarım turizminde onlardan faydalanamamaktadır (Türkben vd. 2012).

Bu çalışmada Amik Ovası'nın tarım turizmi potansiyelinin coğrafi yaklaşımla incelenmesi amaçlanmıştır. Bu çerçevede; "Amik Ovası tarım turizmine elverişli midir? Bu ovada tarım turizmi faaliyetleri yapılabilir mi? Ovanın hangi coğrafi özellikleri tarım turizmi açısından önemlidir? Ovada tarım turizmi potansiyelinin temel unsurlarn nelerdir? Inceleme alanında tarım turizmi potansiyelinin dağılışı nasıldır? Bu dağılışta etkili olan faktörler nelerdir?" şeklindeki araştırma sorularına yanıtlar aranmıştır.

Çalışmanın önemi, öncelikle Amik Ovası için tarım turizmi kapsamında yapılan öncü bir çalışma olmasından kaynaklanmaktadır. Bilhassa bu yayın, daha çok tanıtım ve planlamalar için önem taşımaktadır. Ayrıca elde edilen bulgular ve sonuçlar, konu hakkında kuramsal çalışmalara ve hipo- tezlerin geliştirilmesine yardımcı olabileceği gibi tarım turizminde çalışacak bilim insanlarına da bir kaynak teşkil edebilecektir.

\section{KURAMSAL ÇERÇEVE}

Amik Ovası'nın tarım turizmi potansiyelinin coğrafi açıdan incelenmesinin amaçlandığı bu çalışmanın kuramsal çerçevesini tarım turizmi oluşturmaktadır. Bu turizm türü yirminci yüzyılın başlarından beri dünya alanyazınında tartışılmaktadır (Busby ve Rendle 2000; McKenzie ve Wysocki 2002; Wicks ve Merrett 2003; Gil Arroyo vd. 2013). Bu konu kapsamında birçok çalışma yapılmış ve bu turizm türü çeşitli şekillerde tanımlanmıştır. Irshad (2010) tarım turizmini, en temel kırsal turizm şekli olarak tanımlamıştır. Clarke (1999), Busby ve Rendle (2000), Nickerson vd. (2001), Nilsson (2002) tarım turizminin kırsal turizmin bir alt dalı olup çiftliğe ve çiftçiye dayanmakta olduğunun altını çizmişlerdir. Przezborska (2003) tarım turizmini, tarım ya da çiftlik işleriyle ilgili olarak yapılan her türlü turizm ve rekreasyon aktiviteleri olduğunu belirtmiştir. Ilbery vd. (1998), Fleischer ve Tchetchik (2005) ve Veeck vd. (2006), tarım turizminin faaliyetteki bir çiftlikte ziyaretçilerin tatil amacına uygun olarak yerine getirdiği çiftlik aktivitelerini açıklamak için kullanılan bir terim olduğunu açıklamışlardır. Sharpley ve Vass (2006), tarım turizminin ekonomik amaçlı olarak turizmde çeşitleme yaparak kırsal gelişmede bir katalizör görevi üstlenmekte olduğunu belirtmişlerdir. Kizos ve Iosifides (2007) ise tarım turizmini kırsal alanlarda tarımla uğraşan insanların, küçük ölçekli aile çiftliklerinin geliştirdiği turistik aktiviteler olarak nitelendirmişlerdir. Bütün bu tanımlamalara göre tarım turizmi köylerde tarımla uğraşanlara ek kazanç sağlamak amaciyla tarım veya tarımsal faaliyet alanlarına ziyaret, günlük işlere dahil olma, konaklama, eğlenme, alış-veriş ve eğitimsel amaçla katılımı içine alan aktivitelerin biri veya birkaçını kapsayan turizm türü şeklinde tanımlanabilir (Shaw ve Williams 2002; Türkben vd. 2012). Gerek uluslararas1 gerekse ulusal alanyazında birçok bilim insanı tarafından üzerinde farklı düşünce ve bulgular beyan edilmiş olan tarım turizmine olan ihtiyaç, gün geçtikçe artmaktadır. Bu durum konuyla alakalı olarak daha yeni ve modern çalışmaların yapılmasını gerektirmektedir. Bu bağlamda Türkiye'nin en önemli ovalarından biri olan Amik Ovası örneğin- 
de tarım turizmine uygun potansiyel alanların tespit edilmesi ve potansiyelinin değerlendirildiği bu çalışmanın yapılması da zaruri bir durum şeklini kazanmıştır.

\section{ILGiLi ÇALIŞMALAR}

Son yillarda tarım turizmi konusunda hem dünyada (Weaver ve Fennell 1997; Busby ve Rendle 2000; Przezborska 2003) hem de Türkiye'de (Soykan 2003a; Gündüz 2004; Kiper ve Arslan 2007; Ç1kın vd. 2009; Türkben vd. 2012; Hurma vd. 2012; Selvi ve Demirer 2012) yapılan çalışmalar artmıştır. Bilhassa dünyada bu konuda üzerine çok farklı disiplinler tarafından değişik çalışmalar yapılmıştır. Hjalager (1996), tarımsal işletmelerdeki kırsal turizmin etkilerini tartışmıştır. Clarke (1999), tarım turizminin pazarlama konusundaki yaklaşımını ele almıştır. Aikaterini vd. (2001), Yunanistan'daki tarım turizmi konusundaki politikaların gelişiminde bir gösterge kabul edilen Midilli Adası'ndaki tarım turizmi uygulamalarını açıklamıştır. Nickerson vd. (2001), Amerika'daki küçük aile çiftliklerinin alternatif yatırım amacıyla turizme açıldıklarını ve bunun muhtemel nedenlerini tartışmışlardır. Iakovidou vd. (2001), Orta Makedonya Kerkini Dağı bölgesinde bulunan Selanik'teki potansiyel ziyaretçilerin alternatif turizm biçimi olarak tarım turizmini seçmelerinin nedenlerini ve özelliklerini tanımlamışlardır. Loureiro ve Jervell-Moxnes (2004), Norveç'teki tarım turizmi aktivitelerine kabul edilen işletmelerin finansal durumunu ve sosyo-demografik faktörlerin oynadığı rolü tartışmışlardır. Herrera Catalino ve Lizardo (2004), tarım ve turizm arasındaki bağlantıyı analiz etmişler ve bütüncül bir anlamda, tarımın yerel, bölgesel, ulusal ve küresel sürdürülebilir kalkınmaya katkısı, bunun yanı sıra diğer turizm ile rekabet yeteneğini geliştirmek için potansiyel rollerini değerlendirmiştir. Fleischer ve Tchetchik (2005), çalışma çiftliklerindeki kırsal turizm işletmelerinin tarımsal aktivitenin olmadığı işletmelerden nasıl bir farklılık gösterdiğini araştırmışlardır. Veeck vd. (2006), 300 tane istatiksel analiz ve araştırmaya dayalı olarak Michigan'da bulunan tarım turizmi işletmelerindeki başarılı işletmelerle ilişkili faktörleri özetlemişlerdir. Kizos ve Iosifides (2007), Yunanistan'daki tarım turizminin gelişme durumu hakkında genel bir değerlendirmede bulunmak için üç farklı örnek alan (Lesvos, Magnesia ve Lefkada) seçerek, karşı- laştırma yapmışlardır. Klein vd. (2007) ise çiftliğe gelen ziyaretçilerin çevre üzerindeki olası kirletici ve tahrip edici etkilerini vurgulamışlardır. Plummerw vd. (2008), Ontario çiftliklerini incelemişler, bu çiftliklerin düzenlenmesi ve idaresi kavramları üzerinde durmuşlardır. Albaladejo-Pina ve Dı'azDelfa (2009), köy ve çiftlik gibi kırsal destinasyonlardaki konaklama evlerinin tipi ve kendine has özeliklerinin turistlerin tercihlerini nasıl etkilediğini araştırmışlardır. Henderson (2009), son zamanlarda tarım turizmine yoğun ilginin yaşand1$\breve{g}_{1}$ Singapur örneğinde tarım turizmi kavramını ve uygulamalarını tartışmıştır. Yang vd. (2010), Çin'in başkenti Pekin'deki büyük ölçekli bir tarım turizmi işletmesi olan Xiedao Green Resort'ın 2004-2008 dönemine ait performansını tanımlamışlar ve analiz etmişlerdir. Gil Arroyo vd. (2013), farklı coğrafi ve tarımsal özelliklere sahip olmasına rağmen tarım turizminin gelişim seviyesinin benzer olduğu ABD'nin Missouri ve Kuzey Carolina eyaletlerinde bu turizmin karakterini ve paydaşlarının katılımını incelemişlerdir. Flanigan vd. (2014), araştırmalarında İskoçya genelinde yirmi beş yerde tarım turizmi sağlayıcılarını ve ziyaretçilerin tarım turizmine bakış açılarını incelemişlerdir.

Türkiye'de ise dünyadaki eğilime benzer bir şekilde tarım turizmi konusunda yapılan çalışmalar her geçen gün artmaktadır. Tarlak (2007), çiftlik turizminin bölgesel tanıtıma olan etkisini tartışmıştır. Karabati vd. (2009), Burdur'un Ağlasun Köyü örneğinde yerel toplum üzerinde tarım turizminin temel sosyo-ekonomik etkilerini araştırmışlardır. Ç1kın vd. (2009), tarım turizminin gelişmesi ile turizmin tarımsal turizm üzerindeki olumlu ve olumsuz etkilerini teorik olarak açıklamaya çalışmışlardır. Kılıç ve Kurnaz (2010), Muğla ilindeki Pastoral Vadi Ekolojik Yaşam Çiftliği'ndeki tarım turizmi uygulamalarını nitel araştırma yöntemlerinden örnek olay metodu ile incelemişlerdir. Türkben vd. (2012), Türkiye'de bağcılık yapılan bazı yörelerin tarım turizmi içinde bağcllığın yeri ve önemini ortaya koymaya çalışmışlardır. Selvi ve Demirer (2012), Hindiba Pansiyon ve Özlü Ailesi ekolojik tatil çiftlik işletmelerinde "Ekolojik Çiftliklerde Tarım Turizmi ve Gönüllü Bilgi, Tecrübe Takası" olarak bilinen ve kısa adı "TATUTA" (Tarım-Turizm-Takas) olan projenin uygulanmasinı ve amacina ne derecede ulaştığ sorgulamışlardır. Yavuzaslanoğlu ve Yavuz (2012), Karaman ilinin tarım turizmi yönünden 
potansiyelini incelemişlerdir. Çavuşoğlu (2012), Bozcaada'da üzüm tarımı ve üzümlerin işlenmesi ile uğraşan üreticilerin, sahip oldukları potansiyellerini, ada halkının binlerce yıllık üzüm tarımı tecrübesiyle birleştirerek, günümüzde oldukça rağbet gören tarım turizm aktivitesine dönüştürmeleri gerekliliğini ortaya koymaya çalışmıştır. Gökalp ve Yazgan (2013), kırsal peyzaji planlamada agro ve agri turizm farkı, uygulama şartları, genel özellikleri, Türkiye açısından turizm potansiyeline olan katkıları ve önemlerini incelenmişlerdir.

Yukarıda özetlenen alanyazın ışığında tarım turizmi konusunda yapılan çalışmaları ana başlıklar olarak tarım turizmi pazarlaması (Clarke 1999; Nickerson vd. 2001; Gossling ve Mattson 2002; Soykan 2003a; Loureiro ve Jervell-Moxnes 2004; Çıkın vd. 2009; Albaladejo-Pina ve Dı'az-Delfa 2009), çiftlik turizmi kapsaminda yapilan aktiviteler (Busby ve Rendle 2000; Aikaterini vd. 2001; Douglas vd. 2001; Coombera ve Limb 2004; Herrera Catalino ve Lizardo 2004; Fleischer ve Tchetchik 2005; Veeck vd. 2006; Kizos ve Iosifides 2007; Tarlak 2007; Klein vd. 2007; Plummerw vd. 2008; Kılıç ve Kurnaz 2010; Yang vd. 2010; Türkben vd. 2012; Selvi ve Demirer 2012; Çavuşoğlu 2012), bölgesel tanıtıma olan etkileri (Hjalager 1996; Gündüz 2004; Karabati vd. 2009; Hurma vd. 2012; Gökalp ve Yazgan 2013; Gil Arroyo vd. 2013; Flanigan vd. 2014) ve tarım turizmi potansiyelinin saptanması (Sharpley ve Sharpley 1997; Senes ve Toccolini 1998; Iakovidou vd. 2001; Topay 2003; Kiper ve Arslan 2007; Henderson 2009; Yavuzaslanoğlu ve Yavuz 2012) konuları üzerine yoğunlaştığ görülmektedir. Bu çalışma ise hem çalışma alanı hem çalışmada kullanılan yöntem ve teknikler hem de izlenen yol bakımından ilgili çalışmalardan farklıdır.

\section{YÖNTEM}

Herhangi bir alanda turizm faaliyetlerinin gerçekleştirilmesi, turizme açılması ve turistik amaçla pazarlanabilmesi için envanter çalışmalarla mevcut potansiyelin belirlenmesi gerekmektedir (Efe vd. 2008). Bu tür çalışmalarda potansiyelin belirlenmesi Coğrafi Bilgi Sistemleri (CBS) kullanılarak hazırlanan haritalar üzerinden gerçekleştirilmektedir (Ndubisi 2002; Tozar 2006). Zira CBS ile potansiyel alanlar tespit edilip (Turoğlu ve Özdemir 2005), çeşitli planlamalar yapılabilmektedir (Ölgen 2003;
Kaymaz ve Özşahin 2013). Amik Ovası için de böyle bir yol izlenmiştir.

Çalışmada yöntem olarak Çok Kriterli Karar Verme Yöntemi kullanılmıştır. Bu yöntem, etki eden faktörlerin teorik olarak sinıflandırılması ve duyarlılığa neden olduğu tespit edilen faktör haritalarının çakıştırılarak, duyarlılık sınıflarının yoğunluklarının ve mekânsal dağılışlarının elde edilmesi esasına dayanmaktadır (Koday vd. 2013). Pratik doğası gereği; kaynak tahsisi, tahmin, risk analizi, planlama, performans yönetimi vb. çok çeşitli alanlardaki çalışmalarda uygulanmıştır (Çınar 2004). Tarım turizmi açısından daha çok planlama ve potansiyel belirleme amaçlı olarak kullanıma uygundur. Zira Topay (2003), Bartın Uluyayla'yı; Gündüz (2004), Ankara ilinin Kalecik ilçesini; Kiper ve Arslan (2007) ise Safranbolu Yörükköyü'nü örnek alan çalışmalarıyla bu tür uygulamalar gerçekleştirmişlerdir.

Bu çalışmada ilgili yöntem Saaty (1980) tarafından önerilen (1-9) puanlı tercih ölçeğinden yararlanılarak yapılan puanlama sistemine göre uygulanmiştır. Puanlama ölçeği Kiper ve Arslan (2007) tarafından belirlenen en uygun (9-6), uygun (6-3) ve uygun olmayan (3-1) sonuç sınıfı kategorisinde değerlendirilmiştir. $\mathrm{Bu}$ aşamada belirlenen parametrelerin puanları işlenerek $10 \times 10 \mathrm{~m}$ çözünürlüğünde raster haritalar oluşturulmuştur. Daha sonra ilgili haritalar bir araya getirilerek tarım turizmine uygun potansiyel alanlar haritası elde edilmiştir.

Çalışmada değerlendirilen parametrelere ait materyaller, çok farklı kurum ve kuruluşlardan elde edilen verilerden temin edilmiştir. Bu amaçla Harita Genel Komutanlığı'ndan elde edilen 1/25.000 ölçekli topografya haritalarından yağış, eğim, yerleşme yoğunluğu akarsulara ve yollara uzaklık, Kılıç vd. (2008) ile Kılıç'tan (2011) toprak ve arazi kullanımı, T.C. Devlet Meteoroloji İşleri Genel Müdürlügü'nden temin edilen Antakya (19702011), Samandağ (1970-2011), Altıözü (1986-1993), Reyhanlı (1988-1990), Kırıkhan (1970-2005), Hassa (1976-2004) ve İslahiye (1975-2010) meteoroloji istasyonlarının uzun yıllara ait iklim verilerinden s1caklık ve yağış, Kaymaz ve Özşahin'den de (2013) turistik çekiciliklere uzaklık parametrelerine ait veriler alınmıştır. Bütün bu materyaller CBS destekli olarak ArcGIS/ArcMap 10 paket programinda yöntem içeriği doğrultusunda kullanılmıştır. Bundan sonraki aşamada ise elde edilen veriler, gözlem ve 
görüşmelere dayalı olarak yürütülen saha çalışmalarıyla yerinde denetlenmiştir. Nihai aşamada ise elde edilen sonuçlar SWOT analiziyle değerlendirilmiştir.

\section{ANALIZ VE BULGULAR}

Bu bölüm, öncelikle "Amik Ovası'nın Konumu, Tarım Turizmi Özellikleri ve Çekicilikler", daha sonrada "Coğrafi Bakış Açısıyla Amik Ovası'nın Tarım Turizmi Potansiyeli" olmak üzere iki konu başlığı halinde irdelenmiştir. İlk konu başlığı altında yapılacak açıklamaların ilk bakışta tarım turizmi ile alakası olmadığı düşünülebilir. Ancak bir alanın turizm potansiyelinin ölçülebilmesinde gerekli olan analiz ve teşhis aşamasının tamamlanması için mevcut durumun ortaya konması gerekmektedir (Soykan 2003b). İkinci konu başlı̆̆1 ise turizm potansiyelini saptamanın aşamaları göz önünde bulundurularak kendi içinde üç farklı bölüme ayrılmıştır. Analiz aşaması, tarım turizmi potansiyelinin temel unsurları (arz kaynakları) ve tarım tu- rizmine uygun potansiyel alanların belirlenmesiyle gerçekleştirilmiştir. Teşhis aşaması ise tarım turizmi potansiyelinin değerlendirilmesi kapsamında açıklanmıştır.

\section{Amik Ovası'nın Konumu, Tarım Turizmi Özellikleri ve Çekicilikler}

İnceleme alanı, Doğu Akdeniz havzasında, Türkiye' nin en güneyindeki Hatay ili sınırları içinde yer alan Amik Ovası'na karşılık gelmektedir (Şekil 1). Ova; Coğrafi Koordinat Sistemi'ne göre $36^{\circ} 13^{\prime} 04^{\prime \prime}-36^{\circ} 29^{\prime} 55^{\prime \prime}$ kuzey (N) enlemleri ile $36^{\circ} 11^{\prime} 37^{\prime \prime}-36^{\circ} 14^{\prime} 59^{\prime \prime}$ doğu (E) (UTM Zon 37KWGS84) boylamları arasında bulunur. Kuzeyden Karasu Lav Platosu, batıdan Amanos Dağları, güneyden Kuseyr Platosu ve doğudan da Suriye ile çevrelenmiştir (Şekil 1).

Amik Ovası'nın sulu tarıma uygun yapısı, iklimi ve doğal kaynakları, prehistorik dönemlerden günümüze kadar insan topluluklarının yerleştiği bir alan konumunu kazanmasına neden olmuş-

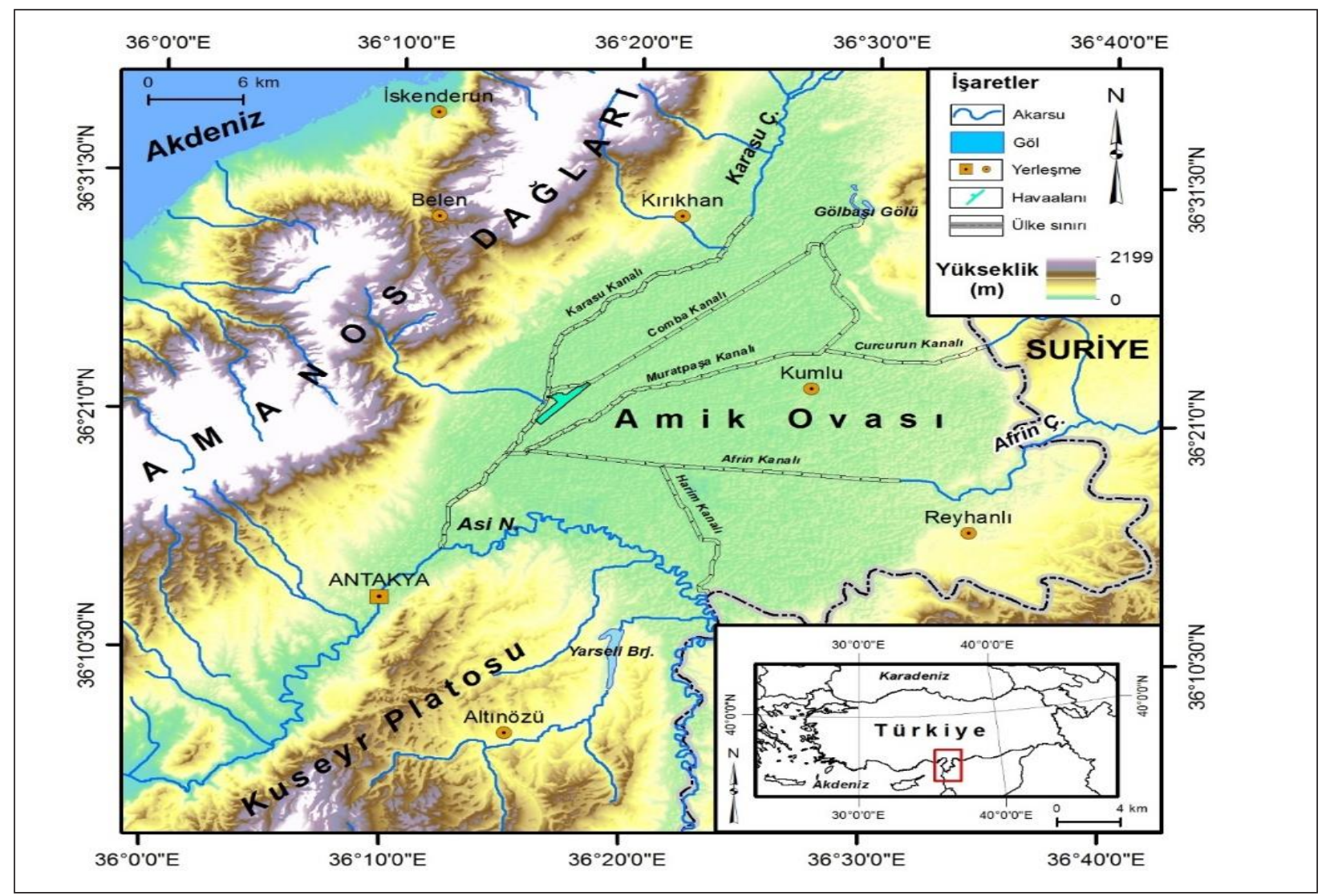

Şekil 1. Amik Ovası'nın Lokasyon Haritası 
tur (Yener 2005; Korkmaz ve Gürbüz 2008; Pamir 2009). Bu bakımdan Anadolu'nun en eski yerleşim alanlarından biri olarak da değerlendirilmektedir (Korkmaz ve Gürbüz 2008 Özşahin ve Kaymaz 2014). Ova aynı zamanda güneyden kuzeye, doğudan batıya uzanan yolların kavşak noktasında bulunması nedeniyle erken dönemlerden itibaren yerleşim birimlerinin oluşması ve sürekliliği bakımindan uygun doğal koşullar sunmuştur (Pamir 2009). Ovanin sunduğu doğal koşullar hem yerleşmelerin oluşmasına hem de tarımın binlerce yıldan bu yana yapılmasına olanak sağlamıştır. Bu zenginlik, günümüzde tarım turizmi için büyük bir potansiyeldir. Ancak bu potansiyel bugüne kadar kullanılmamış, buna karşılık ovada kuş gözlemciliği, tarihi turizm, inanç turizmi ve kaplica turizmi yerini almıştır (Kaymaz ve Özşahin 2013). Aşağıda Amik Ovası'nın tarım turizmi potansiyelinin oluşmasında etkili olan doğal çevre koşulları değerlendirilmiştir.

İklim Özellikleri: Tarım turizminin yapılabilmesi için en önemli faktörlerden biri iklimdir. Tarımsal etkinlikler; sıcaklık, güneşlenme, rüzgâr, nem ve yağış gibi iklim elemanlarıyla yakından ilgili olup tarım etkinliklerinin gerçekleştirilmesi sıkı sıkıya iklim koşullarına bağlıdır (Doğanay ve Coşkun 2012). Karakteristik Akdeniz ikliminin etkilerinin görüldüğü Amik Ovası'nda (Koçman 1993; Çalışkan 2002; Varnac1 2008), kış mevsimi serin, nemli ve yağışlı, yaz mevsimi ise sıcak ve kurak bir özelliktedir (Korkmaz 2009). Ova ve çevresinde yıllık sicaklık ortalaması $17,5-18,5^{\circ} \mathrm{C}$, yillık ortalama toplam yağış miktarları ise 505,2-1078 mm arasındadir. Ortalama nispi nem oranı ise $\% 69$ 'dur (Varnac1, 2008).

Jeomorfolojik Özellikler: Tarım faaliyetleri, jeomorfolojik özelliklerin (yerşekillerinin) uygun olduğu arazilerde gerçekleştirilmektedir. Bu bakımdan ovalık alanlar, birinci derecede tarım arazilerini oluşturur. Tarım turizmi potansiyelinin saptanabilmesi için yerşekillerinin mahiyetinin bilinmesi gerekmektedir. Türkiye'nin en önemli ovalarından birini oluşturan (Karanlık vd. 2010) Amik Ovası'nın kuzey-güney uzunluğu 80-90km, doğubatı genişliği 2-35 km, yükseltisi ise $80-250 \mathrm{~m}$ arasında değişmektedir (Korkmaz 2009). Ovanın çevresindeki dağlardan inen akarsuların ova tabanıyla buluştukları kesimlerde, birikinti konileri ve yelpazeleri yayılış göstermektedir (Zor 2000; Varnacı 2008). Bu jeomorfolojik ünitelerin birleştiği sahalar piedmont kuşağı şeklinde ortaya çıkmıştır (Özşahin ve Değerliyurt 2012).

Hidrografik Özellikler: Hidrografya, tarım alanlarının oluşumu ve tarım şekillerinin (kuru veya sulu) ortaya çıkmasında belirleyici bir etken olarak, tarım üzerinde doğrudan bir etki yapmaktadır. Bu durum dolaylı da olsa tarım turizmi potansiyelinin şekillenmesinde rol oynamaktadir. Amik Ovası, Asi, Karasu ve Afrin nehirlerinin getirdikleri alüvyonların birikmesiyle oluşmuş bir ovadır (Yener vd. 2000; Pamir 2009). Bu akarsular aynı zamanda vadileri aracılığıyla ovayı çevreleyen dağları ve tepelikleri keserek; Amik Ovası'nı Suriye'ye ve Akdeniz'e bağlayan doğal geçitlerdir (Pamir 2009). Ayrıca ovada, 1980 yılına kadar Amik Gölü var olmasına rağmen, günümüzde ise sadece bu gölün bir uzantısı olan (Korkmaz ve Gürbüz 2008; Korkmaz 2008) Gölbaşı Gölü yer alır.

Toprak Özellikleri: Toprak özellikleri, tarım üzerinde iklim kadar önemlidir. Zira toprak, tarımsal etkinliklerin temel ekonomik kaynağ1 ve çiftçilerin en önemli taşınmaz sermayesidir (Doğanay ve Coşkun 2012). Bu sebeple tarım turizmi potansiyelinin oluşmasında mühim bir husus olmaktadır. Amik Ovası, toprak özellikleri açısından değişik tür ve karakterde toprak gruplarının bulunduğu bir alandır (Kılıç vd. 2008). Ovada tarımsal üretimi etkileyen ve ürün çeşidi oluşmasını sağlayan, dolayısıyla tarım turizmine destek veren tarım toprakları Entisol'lerdir (Alüvyal topraklar). Bu topraklar, mineral alterasyonunun çok düşük olduğu (Efe 2010) yeni oluşmaya başlayan genç topraklardır. Bu nedenle toprak horizonları gelişmemiştir (Atalay 2011). Ovada Entisol'lerin iki alt ordosu bulunur. Bunlardan ilki akarsuların taşıyıp, biriktirdikleri sedimentler üzerinde yer alan Fluvent, ikincisi ise eğimli sahalarda ana materyal üzerinde çok ince bir örtü şeklinde olan Orthent'tir. Her iki ordonun da ortak özelliği ana materyalin üzerinde ince bir A horizonunun yer almasıdır (Efe 1999). Fluvent'lerin bulundukları sahaların düz ve düze yakın alanlar olması, Orthent'lere göre daha derin bir toprak yapısı göstermelerine neden olmuştur.

Arazi Kullanımı: Amik Ovası'nda farklı türlerde tarımsal arazi kullanım sınıflarının bulunması (K1lıç 2011), tarım turizmi potansiyelinin oluşmasında belirleyici bir rol oynamaktadır. Ovadaki güncel arazi kullanım şekillerinden seçkin tarım arazileri tarım turizmi bakımından kullanılabilir nitelikte- 
Tablo 1. Hatay İlindeki Tarım Arazileri ve Sulama Durumu

\begin{tabular}{llllll}
\hline $\begin{array}{l}\text { Hatay Ili Arazi } \\
\text { Sulama Durumu }\end{array}$ & $\begin{array}{l}\text { Tarım } \\
\text { Arazisi (ha) }\end{array}$ & $\begin{array}{l}\text { Sulanması } \\
\text { Ekonomik Olmayan } \\
\text { Arazi (ha) }\end{array}$ & $\begin{array}{l}\text { Sulanabilir } \\
\text { Toplam Arazi (ha) }\end{array}$ & $\begin{array}{l}\text { Sulanabilir Ancak } \\
\text { Sulanmayan Arazi (ha) }\end{array}$ & $\begin{array}{l}\text { Sulanan Toplam } \\
\text { Arazi (ha) }\end{array}$ \\
\hline & 275,578 & 69,025 & 206,553 & 30,038 & 176,515 \\
\hline
\end{tabular}

Kaynak: Gıda Tarım ve Hayvancılık Bakanlığı Hatay İl Müdürlüğü 2013.

dir. Ovadaki seçkin tarım arazileri tarımsal anlamda ovanın asıl üretim merkezleridir. Ova için tarla tarımı, primer faaliyetler arasında yer almaktadır. Bu bağlamda ovada yılın her döneminde tarımsal üretim gerçekleştirilmekte ve yıl içinde iki veya üç ürün alınabilmektedir. Günümüze kadar alternatifsiz şekilde yapılan tarımsal faaliyetler içinde buğday 2011 yılı TÜİK rakamlarına göre 780,922 dekarlık ekim alanı ve 321,584 tonluk üretimi ile ovada yetiştirilen ürünler içinde ilk sırayı almaktadır (Bitkisel Üretim İstatistikleri, 2013). Ayrıca pamuk, misır, soğan, sebze ve meyve türleri yoğun olarak üretimi yapılan diğer tarım ürünleridir (Korkmaz 2009).

Tarımsal Üretim: Toplam yüzölçümü 540,300 hektar olan Hatay'da il arazisinin yarısını tarım arazileri oluşturmaktadır. İl genelinde 275,578 hektar tarım arazisi mevcut olup bu arazinin 206,553 hektarı sulamaya elverişlidir. Aynı şekilde toplamda devlet yatırımlı sulamalar 47,005 ha, halk sulamaları ise 129,510 ha'dır. Ayrıca il genelinde Köylere Hizmet Götürme Birliği tarafından açlan sulanabilir alanlarda toplamda 9,953 ha bir alan kaplamaktadır. Amik Ovası ve çevresinde ise Devlet Su İşleri Genel Müdürlüğü tarafından açlan sulama alanlarında ilçelere göre toplam brüt arazi 19,200 ha büyüklügüündedir (Tablo 1).
Aynı şekilde 2012 yılı verilerine göre ildeki toplam tarım arazisinde tarla bitkileri $\% 59$, zeytin $\% 18$, sebze $\% 11$, meyve $\% 10$ oranında paya sahiptir. İl genelinde ilk sırada erik, maydanoz, pazı ve mandalina en fazla üretilen ürünlerdir (Tablo 3). Bunun yanı sıra Hatay, Türkiye ölçeğinde Trabzon hurması, göbekli marul ve taze soğan üretiminde ikinci, taze sarımsak, nane, taze bezelye, taze bamya, havuç, yenidünya ve tere üretiminde ise üçüncü sırada bulunur. Tarımsal üretimin Türkiye genelinde ilk üçe giren oranı incelendiğinde Hatay'ın tarımsal ürün yelpazesi ve potansiyelinin ne ölçüde geniş olduğu daha rahat bir şekilde anlaşılmaktadir (Tablo 3).

Başta Hatay ili olmak üzere Amik Ovası ve çevresi tarımsal üretimin yanında hayvan varlığı bakımından da önemli bir zenginliğe sahiptir. İl genelinde toplamda 139,735 baş büyükbaş, 2083,214 adet kanatlı hayvan, 302,971 baş küçükbaş, 5,904 baş tek tırnaklı hayvan ve 821 adet de arı kovanı bulunur (Tablo 4). Hatay'da hayvansal üretim de önemli değerlere sahiptir (Tablo 5).

Bütün bu tarımsal istatistikler göz önünde bulundurularak ildeki gayrisafi tarımsal gelir toplamda 3174409000,00 TL'dir. Bu gelirin en büyük pay1$\mathrm{n}$ ise 2592312000,00 TL'lik bir tutarla bitkisel üretim toplamı oluşturur (Gıda Tarım ve Hayvancılık Hatay İl Müdürlüğü 2013).

Tablo 2. Amik Ovası ve Çevresindeki İlçelerde Arazi Dağılımı (ha-2012)

\begin{tabular}{llllllr}
\hline İlçeler & Yüzölçümü & $\begin{array}{l}\text { Su yüzeyi ve } \\
\text { Leçelik alan } \\
\text { hariç }\end{array}$ & Tarım Alanı & Mera Alanı & $\begin{array}{l}\text { Orman-Funda- } \\
\text { Tapusuz Konut } \\
\text { Diğer Arazi }\end{array}$ & $\begin{array}{r}\text { Su yüzeyi ve } \\
\text { Leçelik alan }\end{array}$ \\
\hline Antakya & 85,800 & 74,900 & 48,515 & 1,279 & 25,106 & 10,900 \\
\hline Altınözü & 46,800 & 41,700 & 30,116 & 127 & 11,457 & 5,100 \\
\hline Kırıkhan & 84,300 & 72,300 & 43,157 & 3,883 & 25,260 & 12,000 \\
\hline Kumlu & 22,300 & 18,600 & 14,700 & 1,804 & 2,096 & 3,700 \\
\hline Reyhanlı & 41,000 & 40,600 & 32,105 & 1,245 & 7,250 & 400 \\
\hline Toplam & 280,200 & 248,100 & 168,593 & 135,211 & 71,169 & 32,100 \\
\hline
\end{tabular}

Kaynak: Gıda Tarım ve Hayvancılık Hatay İl Müdürlüğü 2013. 
Hatay'da tarımsal amaçlı 65 adet kooperatif ve 18 birlik bulunmaktadır. Bu tarımsal örgütlerin ilçelere dağılımı şöyledir:
- Tarımsal Kalkınma Kooperatifi (32 adet): Yayladağı, Samandağ, Reyhanlı, Kırıkhan, İskenderun, Hassa, Erzin, Dörtyol, Belen, Altınözü, Merkez

Tablo 3. Hatay İli Tarım Ürünlerinin Alanı, Üretim Değerleri ve Türkiye Sıralamasındaki Yeri (2012)

\begin{tabular}{|c|c|c|c|c|c|}
\hline \multirow[t]{2}{*}{ Ürün } & \multirow[t]{2}{*}{$\begin{array}{r}\text { Alan } \\
\text { (da) }\end{array}$} & \multicolumn{2}{|c|}{$\begin{array}{l}\text { Miktar } \\
\text { (Ton) }\end{array}$} & \multirow[t]{2}{*}{$\begin{array}{r}\text { Oran } \\
(\%) \\
\end{array}$} & \multirow[t]{2}{*}{ Sira } \\
\hline & & Hatay & Türkiye & & \\
\hline Erik & 16,926 & 25,528 & 300,046 & 9 & 1 \\
\hline Maydanoz & 18,550 & 21,065 & 56,614 & 37 & 1 \\
\hline Pazı & 2,050 & 3,730 & 5,953 & 63 & 1 \\
\hline Mandalina & 106,987 & 254,288 & 874,832 & 29 & 1 \\
\hline Trabzon Hurması & 4,562 & 6,281 & 32,392 & 19 & 2 \\
\hline Marul (Göbekli) & - & 26,343 & 205,463 & 13 & 2 \\
\hline Soğan (Taze) & 8,070 & 12,060 & 150,928 & 8 & 2 \\
\hline Sarımsak (Taze) & 1,940 & 2,116 & 25,768 & 8 & 3 \\
\hline Nane & 1,365 & 1,048 & 12,598 & 8 & 3 \\
\hline Bezelye (Taze) & 10,850 & 8,930 & 101,959 & 9 & 3 \\
\hline Bamya (Taze) & 2,250 & 2,620 & 36,001 & 7 & 3 \\
\hline Havuç & - & 73,153 & 714,280 & 10 & 3 \\
\hline Yenidünya & 193 & 669 & 12,105 & 6 & 3 \\
\hline Tere & 270 & 162 & 4,476 & 4 & 3 \\
\hline Pamuk (Kütlü) & 417,275 & 210,248 & 2320,000 & 9 & 4 \\
\hline Zeytin (Yağlık) & 403,679 & 146,733 & 1340,000 & 11 & 4 \\
\hline Kuru Sarımsak & 6,934 & 6,456 & 79,433 & 8 & 4 \\
\hline Kabak (Sakız) & & 17,634 & 302,374 & 6 & 4 \\
\hline Patlıcan & 23,081 & 64,882 & 799,285 & 8 & 4 \\
\hline Zeytin (Sofralık) & 91,408 & 32,017 & 480,000 & 7 & 5 \\
\hline İncir & 1,862 & 6,532 & 275,002 & 2 & 5 \\
\hline Limon & 15,850 & 36,990 & 710,211 & 5 & 5 \\
\hline Börülce (Taze) & 1,080 & 1,111 & 20,566 & 5 & 5 \\
\hline Hıyar (Sofralık) & 18,067 & 51,990 & 1603,110 & 3 & 6 \\
\hline Nar & 10,531 & 15,543 & 315150 & 5 & 6 \\
\hline Biber (Salçalık) & - & 48,243 & 748,422 & 6 & 6 \\
\hline Soğan (Kuru) & 56,938 & 117,139 & 1668,356 & 7 & 6 \\
\hline Bakla (Taze) & 1,880 & 2,206 & 40,471 & 5 & 6 \\
\hline Roka & 230 & 170 & 7,689 & - & 7 \\
\hline Bezelye (Kuru) & 471 & 69 & 2,686 & 3 & 8 \\
\hline Yerfıstığı & 1,928 & 596 & 122,780 & & 8 \\
\hline Ispanak & 7,810 & 8,728 & 222,225 & 4 & 8 \\
\hline Pırasa & 2,050 & 6,000 & 229,359 & 3 & 10 \\
\hline Mısır (Dane) & 170,786 & 136,984 & 4600,000 & 3 & 10 \\
\hline Domates (Salçalık) & 40,941 & 139,051 & 7697,961 & 2 & 13 \\
\hline Domates (Sofralık) & 7,210 & 23,189 & 3652,039 & 1 & 14 \\
\hline Buğday (Diğer) & 681,106 & 252,197 & 16800,000 & 2 & 24 \\
\hline Dereotu & 500 & 460 & 2,901 & 16 & 3 \\
\hline
\end{tabular}

Kaynak: Gıda Tarım ve Hayvancılık Hatay İl Müdürlüğü 2013. 
Emre Özşahin - Çağlar Kıvanç Kaymaz

Tablo 4. Hatay'daki Hayvan Varlığ 1 (2013)

\begin{tabular}{|c|c|c|}
\hline Büyükbaş Hayvan & Sayı (Baş) & \\
\hline Saf Kültür Irkı & & 31,886 \\
\hline Kültür Melezi Sığır Sayısı & & 94,499 \\
\hline Yerli Sığır & & 12,601 \\
\hline Manda & & 749 \\
\hline Toplam & & 139,735 \\
\hline Kanatı Hayvan & Sayı (Adet) & \\
\hline Tavuk & & 2072,254 \\
\hline Diğer Kanatlı & & 10,960 \\
\hline Toplam & & 2083,214 \\
\hline Küçükbaş Hayvan & Sayı (Baş) & \\
\hline Koyun & & 168.804 \\
\hline Keçi & & 134.167 \\
\hline Toplam & & 302.971 \\
\hline Tek Tırnaklı Hayvan & Sayı (Baş) & \\
\hline At & & 2,207 \\
\hline Katır & & 429 \\
\hline Eşek & & 3,268 \\
\hline Toplam & & 5,904 \\
\hline Arı Kovanları & Sayı (Adet) & \\
\hline Eski Usul Kovan & & 821 \\
\hline Toplam & & 821 \\
\hline
\end{tabular}

Kaynak: Gıda Tarım ve Hayvancılık Hatay İl Müdürlüğü 2013.

- Sulama Kooperatifi (23 adet): Belen, Dörtyol, Erzin, İskenderun, Kırıkhan, Kumlu, Reyhanlı, Yayladağ 1

- Su Ürünleri Kooperatifi (10 adet): Altınözü, Dörtyol, İskenderun, Samandağ

- Tarımsal Birlik (6 adet): Çuko-Birlik Merkez, K1rikhan, Hassa, Reyhanlı, Kumlu, Erzin

- Sulama Birliği (7 adet): Altınözü, Hassa, Kırıkhan, Samandağ, Yayladağ1

- Yetiştirici Birliği (3 adet): Merkez

- Üretici Birliği (2 adet): Erzin.

\section{Coğrafi Bakış Açısıyla Amik Ovası'nın Tarım Turizmi Potansiyeli}

Tarım Turizmi Potansiyelinin Temel Unsurları (Arz Kaynakları): Turizmin temel unsurları veya arz kay-
Tablo 5. Hatay'ın Hayvansal Ürünler Üretim Değerleri (2013)

\begin{tabular}{lcc}
\hline Ürünün Cinsi & Sayısı & Birimi \\
\hline Yumurta & $103.882,000$ & Adet \\
\hline Kırmızı Et & 8,600 & Ton \\
\hline Beyaz Et & 3,400 & Ton \\
\hline Süt & 225,000 & Ton \\
\hline Bal & 1,073 & Ton \\
\hline Su Ürünleri & 3350 & Ton \\
\hline Yapağı & 105 & Ton \\
\hline Keçi Kılı & 45 & Ton \\
\hline Kaynak: Gıda Tarım ve Hayvancılık Hatay İl Müdürlü̆̆̈̈ 2013.
\end{tabular}

nakları; çekicilikler, erişim ve konaklamadan oluşmaktadır. Bu üç unsurun yeterli olması ve organizasyon bütünlüğü, turizmde gelişmenin temel yapı taşlarıdır (Özgüç 2007).

Turizmin temel unsurlarından ilki, çekiciliktir. Aslında bu unsur, turizmin yer seçiminde rol oynayan coğrafi kaynaklardır ve turistin bir alanı ziyaret etme isteğini doğurur (Özgüç 2007). Nitekim Amik Ovası'nın tarım turizmi için yeterli potansiyele sahip olması doğal ortam özelliklerinin bu turizmin yapılmasına imkân vermesinden kaynaklanmaktadır. Ovada farklı türlerde tarımsal arazi kullanım sınıflarının bulunması (Kılıç 2011), tarım turizmi potansiyelinin oluşmasında belirleyici bir rol oynamaktadır. Bunun yanında ovanın bazı kesimlerinde tarımsal üretime katılan çiftlikler de mevcuttur. Buna mukabil ova sınırları içinde yapılan veya yapılabilecek olan başta kaplıca turizmi olmak üzere doğa yürüyüşü, kuş gözlemciliği, yaban hayatı gözlemciliği, av turizmi, balon turizmi, tarihi turizm ve inanç turizmi gibi turizm faaliyetleri de (Kaymaz ve Özşahin 2013) tarım turizmini destekleyecek ve tamamlayacak diğer özelliklerdir.

Turizmin temel unsurlarından ikincisi ise erişimdir. Erişim, turizmde ziyaretin gerçekleştirilebilmesini sağlayan ulaşım ve iletişim hizmetleri olarak bilinir (Özgüç 2007). Amik Ovası'nın tarım turizmi açısından erişim imkânları da oldukça gelişmiştir. Ovadaki tarım dışı arazilerden bir kısmına karayolları ve Hatay Havaalanı yerleşmiştir. Bu özellik gerek karayolu gerekse havayolunu kullanarak bu bölgeye gelen turistler için oldukça cazip bir durumdur. 
Turizmin temel unsurlarından sonuncusu da konaklamadır. Bu unsur, turistin gidilen yerde ağırlanmasını sağlar (Özgüç 2007). Bu yönden değerlendirildiğinde Amik Ovası'nda tarım turizmi kapsamında özel oluşturulan mekânlar şu anda yoktur. Ancak yakın gelecekte özellikle de ovada yer alan köylerde bu türden geleneksel ve otantik konaklama mekânları oluşturulabilir.
Tarmm Turizmine Uygun Potansiyel Alanlar: Amik Ovası'nda tarım turizmine uygun potansiyel alanların saptanması, alanyazında yer aldığı gibi (Kiper ve Arslan 2007) ArcGIS/ArcMap 10 paket programiyla CBS destekli olarak Çok Kriterli Karar Verme Yöntemi ile gerçekleştirilmiştir. Tarım turizmi potansiyelinde etkili parametreler ise ilgili alanyazın ve arazi çalışmaları eşliğinde toplanan veriler 1ş1-

Tablo 6. Tarım Turizmi Potansiyelinde Etkili Parametreler

\begin{tabular}{|c|c|c|c|}
\hline Etkili Parametreler & Parametre Sınıfları & Etki Değeri & Ağırlık Değeri \\
\hline \multirow[t]{2}{*}{ Sıcaklık $\left({ }^{\circ} \mathrm{C}\right)$} & Hafif sıcaklık (<-18) & 1 & 3 \\
\hline & Konforlu sıcaklık $(18,01->)$ & 9 & \\
\hline \multirow[t]{5}{*}{ Yağış (mm) } & $<-600$ & 9 & 3 \\
\hline & $600,01-700$ & 7 & \\
\hline & $700,01-800$ & 5 & \\
\hline & $800,01-900$ & 3 & \\
\hline & $900,01->$ & 1 & \\
\hline \multirow[t]{6}{*}{ Eğim (\%) } & Düz ve düze yakın (0-1) & 9 & 3 \\
\hline & Hafif eğimli (1,01-3) & 8 & \\
\hline & Orta eğimli $(3,01-8)$ & 7 & \\
\hline & Çok eğimli $(8,01-15)$ & 5 & \\
\hline & Aşırı parçalanmış arazi $(15,01-40)$ & 3 & \\
\hline & Dağlık arazi $(40,01->)$ & 1 & \\
\hline \multirow[t]{5}{*}{ Akarsulara Uzaklık (m) } & Çok yakın $(<-20)$ & 1 & 5 \\
\hline & Yakın (20,01-60) & 3 & \\
\hline & Orta uzak $(60,01-100)$ & 5 & \\
\hline & Uzak $(100,01-140)$ & 7 & \\
\hline & Çok uzak $(140,01->)$ & 9 & \\
\hline \multirow[t]{5}{*}{ Toprak } & Entisol & 9 & 7 \\
\hline & Vertisol & 5 & \\
\hline & İnceptisol & 5 & \\
\hline & Alfisol & 7 & \\
\hline & Mollisol & 3 & \\
\hline \multirow[t]{5}{*}{ Arazi Kullanımı } & Seçkin tarım arazileri & 9 & 9 \\
\hline & Oldukça iyi tarım arazileri & 7 & \\
\hline & Sorunlu tarım arazileri & 5 & \\
\hline & Tarımda kullanımı sınırlı araziler & 3 & \\
\hline & Tarım dışı araziler & 1 & \\
\hline \multirow[t]{5}{*}{ Yerleşme Büyüklüğü (kişi) } & Az Seyrek & 1 & 5 \\
\hline & Seyrek & 3 & \\
\hline & Orta yoğun & 5 & \\
\hline & Yoğun & 7 & \\
\hline & Çok yoğun & 9 & \\
\hline \multirow[t]{5}{*}{ Yollara Uzaklık (m) } & Çok yakın $(<-30)$ & 9 & $\overline{7}$ \\
\hline & Yakın $(30,01-60)$ & 7 & \\
\hline & Orta uzaklıkta $(60,01-90)$ & 5 & \\
\hline & Uzak $(90,01-120)$ & 3 & \\
\hline & Çok uzak $(120,01->)$ & 1 & \\
\hline \multirow[t]{5}{*}{ Turistik Çekiciliklere Uzaklık (m) } & Çok yakın & 9 & 3 \\
\hline & Yakın & 7 & \\
\hline & Orta uzaklıkta & 5 & \\
\hline & Uzak & 3 & \\
\hline & Çok uzak & 1 & \\
\hline
\end{tabular}


ğında tespit edilmiştir. Buna göre Amik Ovası'nda tarım turizmi potansiyeline uygun alanların dağılışında etkili parametreler sıcaklık, yağış, eğim, akarsulara uzaklık, toprak, arazi kullanımı, yerleşme yoğunluğu, yollara uzaklık ve turistik çekiciliklerdir (Tablo 6).

Aslında bu parametrelerden sıcaklık, yağış, eğim, akarsulara uzaklık, toprak ve arazi kullanı$\mathrm{m}$, doğrudan tarımla ilgili faktörlerdir. Tarım turizminde ise esas olarak; tarımsal alanlar ve onların peyzajları, tarımsal ürünler, tarımsal yöntemler ve etkinlikler, tarımsal işletmeler, ulaşım ve konaklama hizmetleri, yerel kültürel özellikler, doğal çeki- cilikler vd. etkilidir ve bunlar turistik talebi yaratır. Ancak Amik Ovası'nda, tarım turizmine uygun potansiyel alanlar, veri temini ve toplama sikıntıS1 yaşandığı için sadece tarımla ilgili parametreler dikkate alınarak belirlenmiştir. Çalışmanın zayıf yönü olarak değerlendirilebilecek bu kısım daha sonra eksik veriler toplandıktan sonra yapılacak başka çalışmalarla giderilebilir. Buna mukabil mevcut durumun hâlihazırdaki verilerle potansiyel saptanmasına yönelik olarak kullanılmasında herhangi bir sakınca yoktur (Kiper ve Arslan 2007).

Amik Ovası'nda yıllık ortalama sıcaklık 17,5-18,5 ${ }^{\circ} \mathrm{C}$ arasındadır. Turizmde etkili olan termal konfor

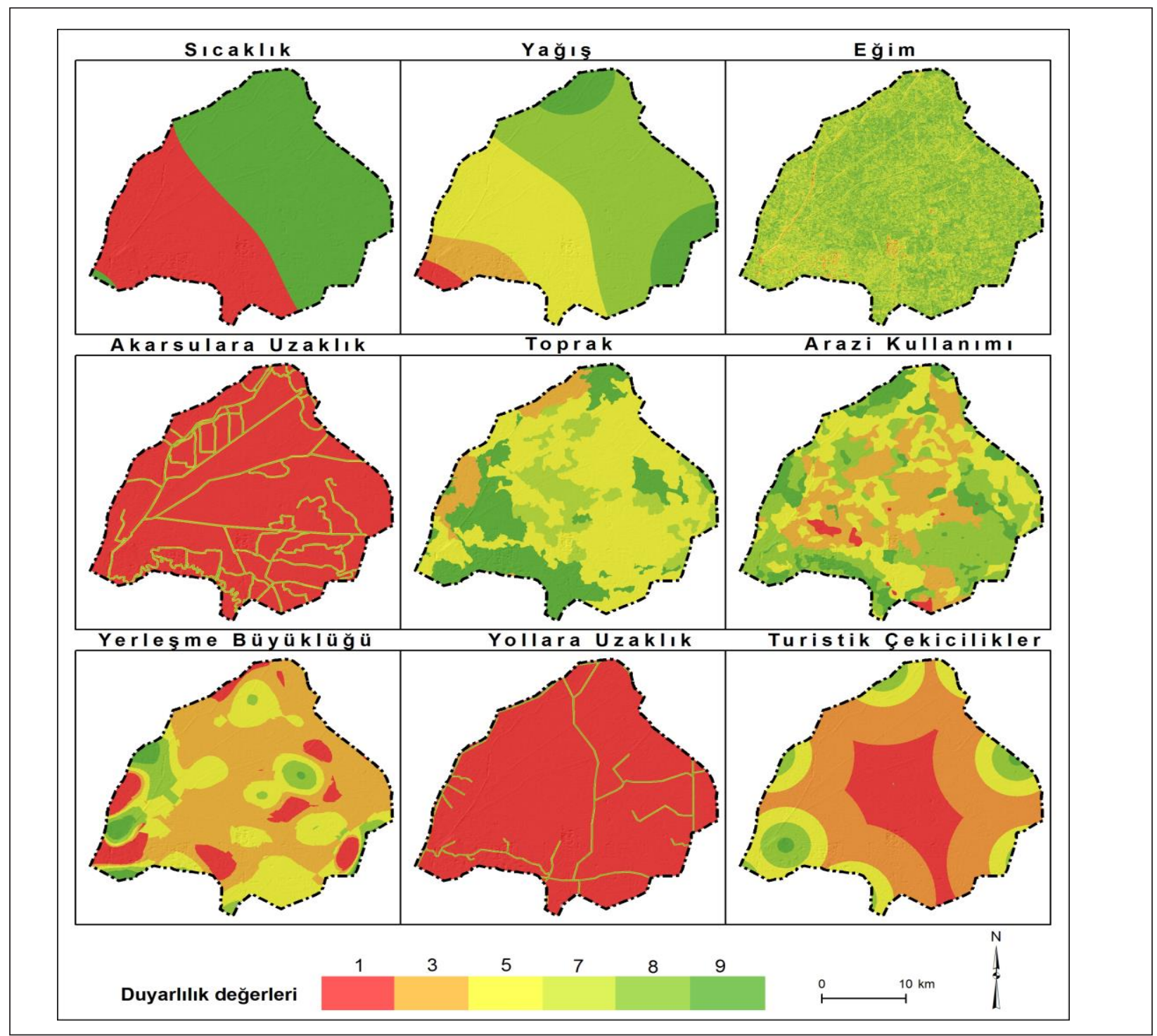

Şekil 2. Amik Ovası'nın Tarım Turizmi Potansiyelinde Etkili Olan Parametreler 
Tablo 7. Amik Ovası'nın Uygunluk Sınıflarına Göre Tarım Turizmi Potansiyel Alanları (ha- $\%$ )

\begin{tabular}{lrr}
\hline Uygunluk Sınıfları & Alan $(\mathrm{Ha})$ & Oran (\%) \\
\hline En uygun alanlar & 55920,37 & 77,20 \\
\hline Uygun alanlar & 16474,45 & 22,74 \\
\hline Uygunsuz alanlar & 38,92 & 0,05 \\
\hline Toplam & 72433,74 & 100,00 \\
\hline
\end{tabular}

aralığına göre (Topay 2013), ovada sıcaklık değerlerinin $18^{\circ} \mathrm{C}^{\prime}$ nin üzerinde olduğu yerler en konfor$\mathrm{lu}$, altında olduğu yerler ise hafif serin yerlerdir. $\mathrm{Bu}$ bakımdan değerlendirildiğinde Amik Ovası'nda tarım turizmi bakımından hem en uygun, hem de uygun olmayan değerlerde alanlar bulunmaktadır.

Tarım turizmi potansiyeli açısından yağış koşulları da önemlidir. Turizm aktiviteleri açısından az yağışlı sahalar daha makbuldür (Özgüç 2007; Güçlü 2010). Amik Ovasi'nda en uygundan, uygun olmayana kadar çeşitli hassasiyet derecelerinde yıllık ortalama yağış miktarları mevcuttur.

Eğim özellikleri de tarım turizminde etkili bir parametredir (Kiper ve Arslan 2007). Amik Ovas1 için ilgili faktör, Altınbaş (2006) tarafından tarımsal amaçlı çalışmalarda kullanılan eğim sınıfları dikkate alınarak hazırlanmış ve genellikle düz, hafif ve orta eğim sınıflarının hâkim olduğu bir dağılışla karşılaşılmıştır.

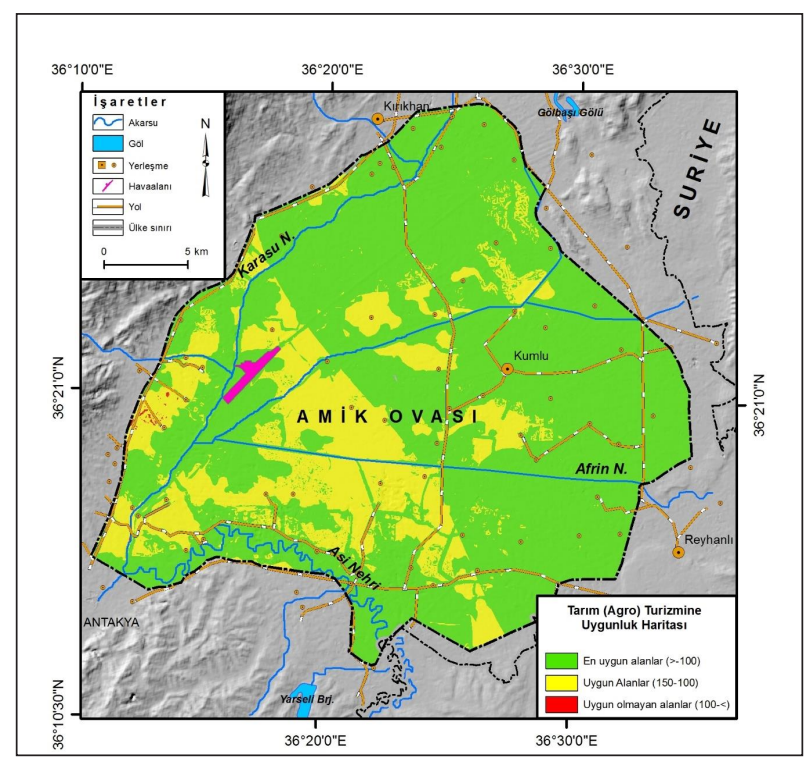

Şekil 3. Amik Ovası'nın Uygunluk Sınıflarına Göre Tarım Turizmi Potansiyel Alanları
Tarım turizmi potansiyelinde akarsuların varlığ 1 ve uzaklığı önemli bir doğal çekicilik yarattığı gibi akarsuların bazı olumsuz etkilerde bulundukları da görülmektedir (taşkınlar, bataklık alanlar vd.) (Kiper ve Arslan 2007). Çeşitli büyüklükteki akarsular tarafından drene edilen Amik Ovası'nda tarımsal faaliyetler üzerinde akarsular rol oynamakta, böylece tarım turizmine uygun ve uygun olmayan alanlar ortaya çıkmaktadır. Bu faktörün etki derecesinin dağılışına göre uygun olmayan yerler daha geniş alanlarda yayılış göstermektedir.

Tarımsal faaliyetlerin üzerinde gerçekleştirildiği toprak da tarım turizminde etkili en önemli parametrelerden biridir (Kiper ve Arslan 2007). Beş tür toprak grubunun bulunduğu Amik Ovası'nda, tarım turizmi açısından ilgili toprak grupları, verimlilik ve tarıma uygunluk açısından farklı türde hassasiyetlere sahiptir.

Amik Ovası'nda tarım turizminde egemen temel parametre arazi kullanımıdır. Farklı şekillerde arazi kullanımın yaygın olduğu ovada, kullanım sinıflarının hassasiyet dereceleri tarım dışı arazilere doğru düşerek, tarım turizmine uygun olmayan bir karakter kazanır.

Tarım turizmi potansiyelinde kırsal yerleşmelerin (köy, kasaba, çiftlik vd.) varlığı ve bunların otantikliğini korumuş olması çok önemlidir. Ayrıca, yerleşmelerin şekli (toplu-dağınık), planı ve dağılış dokusu da tarım turizmini etkileyebilmektedir. Ovada yerleşme büyüklüğü 8-14093 hane arasında değişmektedir.

Ulaşım-erişim olanakları kapsamında yollara uzaklık da tarım turizmi faaliyetleri bakımından değerlendirilmesi gerekli olan başka bir faktördür (Kiper ve Arslan 2007). Zira tarım turizmi bir çiftlik veya bir köyde konaklamayla gerçekleşeceği için, bu tür faaliyetlerin de tarım turizmi bakımından uygunluğunun sorgulanması gerekir. Amik Ovası'nda bu faktörün etkisi daha çok uygun olmayan alanlarla temsil edilmektedir.

Amik Ovası'ndaki hâlihazırda bulunan turistik mekânlara uzaklık da tarım turizmi açısından egemen bir unsurdur. Amik Ovası'ndaki turistik mekânlar (Kaplıca turizmi: Ottoman Palace, Hamamat Otel, Yaban Hayatı Gözlemciliği: Gölbaşı Gölü) (Kaymaz ve Özşahin 2013) tarım turizmi için destekleyici olabilir. Çünkü günümüzde bir turizm türünü ne kadar çok başka turizm türleri ve akti- 
viteleri tamamlıyorsa (bütünleşik turizm), o yerin talep potansiyeli de o kadar artmaktadır. Çeşitli türde turizm etkinliklerinin bulunduğu bu sahada (Kaymaz ve Özşahin 2013), bu turizm merkezlerine yaklaştıkça tarım turizm potansiyeli daha uygun bir hassasiyet kazanır.

Amik Ovası'nın tarım turizmi potansiyelinde etkili olan yukarıda açıklanan faktörlerin ağırlık değerleri ölçüsünde gerçekleştirilen analiz sonucunda elde edilen tarım turizmine uygun alanlar haritasına göre ovanın $\% 99$ 'u en uygun ve uygun alanlardan oluşmaktadır (Tablo 7). Ovanın genelinde yayılış gösteren bu sahalara karşın, tarım turizmi bakımından uygunsuz sahalar ise Hatay Havaalanı'nın batısında bulunmaktadır (Şekil 3).

Tarım Turizmi Potansiyelinin Değerlendirilmesi: Amik Ovası'nın tarım turizmi potansiyeli, anlamayı, algılamayı, karar almayı kolaylaştıran (Özçağlar vd. 2006) ve konuyu tüm yönleriyle ortaya koyan (Taş 2009) SWOT analizi (Güçlü Yönler, Zayıf Yönler, Fırsatlar ve Tehditler) ile değerlendirildiğinde planlamaya yönelik bazı sonuçlar elde edilmiştir (Tablo 8).

SWOT analizi çerçevesinde yapılan değerlendirmeler doğrultusunda Amik Ovası'nda tarım turizmi açısından görülen en önemli zayıf yön; bilgi ve bilinç eksikliğinin olmasıdır (Tablo 8). Bu zayıflı̆̆ın giderilmesi için tarım turizmi hakkında eğitimsel çalışmalar yapılmalıdır. Bunun yanında konaklama hizmetlerinin olmaması, herhangi bir altyap1nın olmaması ve nitelikli eleman eksiliği de diğer zayıf yönlerdir (Tablo 8). Ovada sık sık yaşanan taşkınlar ve tarım arazilerinin çok parçalı olması ise tehditler olarak gösterilebilir (Tablo 8). Tarım turizmi açısından Amik Ovası'nın güçlü yönleri ise tarımsal potansiyeli yüksek bir alan olması ve doğal çekiciliklerin zengin olmasıdır (bölgeye özgü tarımsal ürünler, ürünlerin çok çeşitli olması ve mevsimlere göre farklılıklar taşıması, geniş ekim alanlarının olması vd.). Ayrıca yöre insanının bu tür faaliyetlere sıcak bakması da diğer güçlü bir yöndür (Tablo 8). Nitekim saha çalışmaları esnasında yaptığımız görüşmeler bu durumu teyit etmektedir. Ovada karşılaşılan fırsatlar ise bölgenin çok çeşitli insan profiline sahip olması, farklı turistik mekânların bulunması, zengin ve birbirinden farklı kültürel mirasın varlığı ve Neolitik tarım kültürünün ilk ortaya çıtığı Mezopotamya'ya olan yakınlığı, ulaşım kolaylıklarının olması olarak sayılabilir (Tablo 8).

\section{SONUÇ}

Dünya'da ve Türkiye'de son yıllarda yükseliş ivmesi kazanan turizm türlerinden biri de tarım turizmidir. Türkiye'de tarım turizminin her mevsim yapılabileceği alanlardan biri de Amik Ovası'dır. Yapılan bu çalışmanın Amik Ovası dahilinde yürütülmesi, elde edilen sonuçların da bu alanda geçerli olmasına neden olmuştur. Bu makalede Amik Ovası'nın tarım turizmi potansiyeli, ilkeler ve sistematik olarak coğrafi bakış açısıyla ele alınmıştır. Elde edilen bulgular, gelecekte yapilacak benzer çalışmalara temel teşkil edebilecektir.

Burada araştırma sorularına geri dönülürse, Amik Ovası'nın tarım turizmine elverişli olduğu anlaşılmıştır. Bu ovada tarım turizmi faaliyetleri yapılabilir. Ovanın iklim, jeomorfoloji, hidrografya, toprak ve arazi kullanımı gibi coğrafi özellikleri tarım turizmi açısından önemlidir. Ovada tarım turizmi potansiyelinin temel unsurları; çekicilikler, erişim ve konaklamadır. İnceleme alanının \%99'u tarım turizmi potansiyeline en uygun ve uygun alanlardan oluşmaktadır. Bu dağılışta sıcaklık, yağış, eğim, akarsulara uzaklık, toprak, arazi kullanı$\mathrm{ml}$, yerleşme yoğunluğu, yollara uzaklık ve turistik çekicilikler gibi faktörler etkili olmuştur.

Günümüze kadar Amik Ovası'nda tarım turizmi kapsamında herhangi bir faaliyet yapılmamıştır. Ovada tarım turizmi için doğal ve kültürel çekicilikler ile ulaşım olanakları yeterli düzeyde olmasına rağmen, konaklama hizmetleri gelişmemiştir.

Bu bağlamda öncelikli olarak yapılması gerekenler şunlardır:

- Amik Ovası'nda tarım turizminin geliştirilmesi için bir plan ve bu plana dayalı projeler hazırlanmalıdir.

- Amik Ovası'nda tarım turizmi için kullanılacak yerler tespit edilmeli ve turizme yönelik iyileştirmeler ve düzenlemeler (özellikle altyapı) yapılmalıdir.

- Tarım turizmi için yeme-içme, alışveriş ve konaklama mekânları oluşturulmalıdır.

- Turistler için tarım turizmi çerçevesinde her mevsime özgü etkinlikler düzenlenmelidir (festival, şenlik vd.) 
Şekil 8. Amik Ovası'nın Tarım Turizmi Potansiyeline Yönelik SWOT Analizi

\begin{tabular}{|c|c|c|c|}
\hline Güçlü Yönler & Zayıf Yönler & Fırsatlar & Tehditler \\
\hline $\begin{array}{l}\text { Ova'nın Türkiye geneline } \\
\text { hitap edici bir yetkinliğe } \\
\text { sahip olması }\end{array}$ & $\begin{array}{l}\text { Tarımsal turizm } \\
\text { konusundaki bilgi ve bilinç } \\
\text { eksikliğinin olması }\end{array}$ & $\begin{array}{l}\text { Bölgenin çok çeşitli insan } \\
\text { profiline sahip olması }\end{array}$ & $\begin{array}{l}\text { Ovada sık sık } \\
\text { taşkınların yaşanması }\end{array}$ \\
\hline $\begin{array}{l}\text { Tarımsal potansiyeli yüksek } \\
\text { bir alan olması }\end{array}$ & $\begin{array}{l}\text { Konaklama hizmetlerinin } \\
\text { olmaması }\end{array}$ & $\begin{array}{l}\text { Farklı turistik mekânların } \\
\text { bulunması }\end{array}$ & $\begin{array}{l}\text { Tarım arazilerinin çok } \\
\text { parçalı olması }\end{array}$ \\
\hline $\begin{array}{l}\text { Doğal çekiciliklerin zengin } \\
\text { olması }\end{array}$ & $\begin{array}{l}\text { Tarım turizmine yönelik } \\
\text { herhangi bir alt yapının } \\
\text { olmaması }\end{array}$ & $\begin{array}{l}\text { Zengin ve birbirinden farklı } \\
\text { kültürel mirasın varlığı }\end{array}$ & $\begin{array}{l}\text { Seracılık faaliyetlerinin } \\
\text { yeterince gelişmemiş } \\
\text { olması }\end{array}$ \\
\hline $\begin{array}{l}\text { Yöre insanın turizme } \\
\text { yabancı olmaması }\end{array}$ & $\begin{array}{l}\text { Tarım turizminde çalışacak } \\
\text { nitelikli eleman eksikliği }\end{array}$ & $\begin{array}{l}\text { Neolitik tarım kültürünün ilk } \\
\text { ortaya çıtığı } \\
\text { Mezopotamya'ya yakınlık }\end{array}$ & $\begin{array}{l}\text { Yaz mevsiminde } \\
\text { kuruyan veya debisi } \\
\text { azalan akarsuların } \\
\text { sulama için yetersiz } \\
\text { kalması }\end{array}$ \\
\hline $\begin{array}{l}\text { Tarihin ilk dönemlerinden } \\
\text { itibaren günümüze kadar } \\
\text { tarımsal üretimin yapılıyor } \\
\text { olması }\end{array}$ & $\begin{array}{l}\text { Tarımsal potansiyelin tarım } \\
\text { turizmi açısından } \\
\text { değerlendirilememesi } \\
\text { (tarımsal ürünlerin turistik } \\
\text { ürüne çevrilememesi) }\end{array}$ & $\begin{array}{l}\text { Ulaşım kolaylıklarının } \\
\text { olması }\end{array}$ & $\begin{array}{l}\text { Yaz mevsiminde aşırı } \\
\text { taban suyu kullanımı ve } \\
\text { taban suyu seviyesinin } \\
\text { düşmesi }\end{array}$ \\
\hline $\begin{array}{l}\text { Tarımsal ürün yelpazesinin } \\
\text { oldukça geniş ve verimin } \\
\text { yüksek olması }\end{array}$ & $\begin{array}{l}\text { Tarımla alakalı birliklerinin } \\
\text { yetersiz olması, tarımsal } \\
\text { ürünlerin pazarlanmasında } \\
\text { güçlüklerin yaşanması }\end{array}$ & $\begin{array}{l}\text { Yöreyle özdeşleşmiş kaliteli } \\
\text { marka ürünlerin yaygın } \\
\text { olması, kent halkının ve } \\
\text { turistlerin ekolojik tarım } \\
\text { ürünlerine olan talebinin } \\
\text { giderek artması }\end{array}$ & $\begin{array}{l}\text { Ovada halen devam } \\
\text { eden anız yakımı ile } \\
\text { toprağa zarar verilmesi }\end{array}$ \\
\hline $\begin{array}{l}\text { Ovada çok sayıda kırsal } \\
\text { yerleşmenin bulunması ve } \\
\text { temel geçim kaynağının } \\
\text { tarım olması, tarımsal } \\
\text { faaliyetlere önem verilmesi }\end{array}$ & $\begin{array}{l}\text { Tarımsal üretimde kota } \\
\text { uygulamalarının olması }\end{array}$ & $\begin{array}{l}\text { Gıda, Tarım ve Hayvancılık } \\
\text { Bakanlığı'nın kırsal } \\
\text { kalkınma, ekolojik tarım vb. } \\
\text { birçok alanda projelerin } \\
\text { yürütülmesine hız vermesi }\end{array}$ & $\begin{array}{l}\text { Taban suyu kullanımı } \\
\text { için açılan kuyu } \\
\text { sayısının her geçen gün } \\
\text { artması }\end{array}$ \\
\hline $\begin{array}{l}\text { Makinalı tarımın yaygın } \\
\text { olması }\end{array}$ & $\begin{array}{l}\text { Ürünlerin taban fiyatlarının } \\
\text { düşük olması }\end{array}$ & $\begin{array}{l}\text { Tarımsal faaliyetlerin yörede } \\
\text { istihdam yaratması }\end{array}$ & $\begin{array}{l}\text { Tarım topraklarında } \\
\text { aşırı sulamaya bağlı } \\
\text { olarak toprak veriminin } \\
\text { düşmesi }\end{array}$ \\
\hline $\begin{array}{l}\text { Ovanın ulaşım yollarına } \\
\text { yakın olması }\end{array}$ & $\begin{array}{l}\text { Tarımdan elde edilen gelirin } \\
\text { düşük olması }\end{array}$ & $\begin{array}{l}\text { Bilimsel faaliyetlerin } \\
\text { yürütüldüğü üniversite ve } \\
\text { benzeri kuruluşların varlığı }\end{array}$ & $\begin{array}{l}\text { Kırsal kesimde yaşayan } \\
\text { genç nüfusun tarım dışı } \\
\text { sektörlerde çalışmak } \\
\text { üzere ülke içine ve ülke } \\
\text { dışına (Ortadoğu'daki } \\
\text { Arap ülkeleri vd.) göç } \\
\text { etmesi }\end{array}$ \\
\hline $\begin{array}{l}\text { Ovaya komşu alanlarda } \\
\text { başka turizm çekiciliklerinin } \\
\text { ve turistik mekânların } \\
\text { bulunması }\end{array}$ & $\begin{array}{l}\text { Tarım turizminin } \\
\text { geliştirilmesi konusunda geç } \\
\text { kalınması }\end{array}$ & $\begin{array}{l}\text { Halkın tarım turizmine sıcak } \\
\text { bakması }\end{array}$ & $\begin{array}{l}\text { Ovadaki Amik Gölü } \\
\text { başta olmak üzere bazı } \\
\text { su kaynaklarının } \\
\text { kurutulması }\end{array}$ \\
\hline $\begin{array}{l}\text { Bölgenin her mevsim tarım } \\
\text { turizmi faaliyetlerinin } \\
\text { yapılmasına olanak vermesi }\end{array}$ & $\begin{array}{l}\text { Ekolojik tarımın geliştirilmesi } \\
\text { için yeterli teşvik ve } \\
\text { bilgilendirilmenin } \\
\text { yapılmaması }\end{array}$ & $\begin{array}{l}\text { Yöreye özgü marka } \\
\text { ürünlerin (defne sabunu, } \\
\text { zeytinyağı, nar ekşisi vd.) } \\
\text { tarım turizminin gelişmesi } \\
\text { için bir fırsat ve reklam aracı } \\
\text { olması }\end{array}$ & $\begin{array}{l}\text { Ovanın siyasi } \\
\text { sınırlarımıza yakın } \\
\text { olması ve Ortadoğu'da } \\
\text { yaşanan sıkıntılar }\end{array}$ \\
\hline
\end{tabular}


- Tarım turizmi kapsamında yerel halka eğitimler (seminerler, kurslar, uygulama gezileri vd.) verilmelidir.

- Tarım turizmi konusunda yerel örgütlenmeye gidilmeli, yapılan tüm çalışmalara yerel halk dâhil edilmelidir.

- Bütün bu faaliyetler sonucunda tarım turizmine hazırlanan Amik Ovası, etkili bir şekilde tanıtılmalı ve pazarlanmalıdır.

\section{KAYNAKÇA}

Aikaterini, G., Ioannis, S., Thanasis K. (2001). Is Agrotourism 'Agro' or 'Tourism'? Evidence from Agrotourist Holdings in Lesvos, Greece, Anatolia: An International Journal of Tourism and Hospitality Research, 12 (1): 6-22.

Ak, İ. (2006). Turizmde Yeni Seçenekler: Eko-Turizm ve Tarım Turizmi, Türkiye 3. Organik Tarrm Sempozyumu, Atatürk Bahçe Kültürleri Merkez Araştırma Enstitüsü, 475-481, Yalova.

Albaladejo-Pina, I. P., Dı'az-Delfa, M. T. (2009). Tourist Preferences for Rural House Stays: Evidence From Discrete Choice Modelling in Spain, Tourism Management, 30: 805-811.

Altınbaş, Ü. (2006). Toprak Etüt ve Haritalama. İzmir: Ege Üniversitesi Yayınları Ziraat Fakültesi Yayın No: 521.

Atalay, İ. (2011). Toprak Oluşumu, Stnıflandırması ve Coğrafyası. İzmir: Meta Basım Matbaacılık Hizmetleri.

Bitkisel Üretim İstatistikleri (2013). http://tuikapp.tuik.gov.tr/bitkiselapp/bitkisel.zul, Erişim Tarihi: 15 Ağustos 2013.

Busby, G. ve Rendle, S. (2000). The Transition From Tourism on Farms to Farm Tourism, Tourism Management, 21 (6): 635-642.

Clarke, J. (1999). Marketing Structures for Farm Tourism: Beyond the Individual Provider of Rural Tourism, Journal of Sustainable Tourism, 7 (1): 26-47.

Coombera, L. ve Limb, C. (2004). Farm Tourism: A Preliminary Study of Participants' Expectations and Perceptions of Farm Tours, International Environmental Modelling and Software Society iEMSs 2004, International Conference, 1417 Haziran 2004, Osnabrück Üniversitesi, Almanya.

Çalışkan, V. (2002). Amik Ovası'nın Beşerî ve İktisadî Coğrafyası. (Yayımlanmamış Doktora Tezi). İstanbul Üniversitesi Sosyal Bilimler Enstitüsü Beşerî ve İktisadî Coğrafya Anabilim Dalı, İstanbul.

Çavuşoğlu, M. (2012). Bozcaada Üzüm Tarımı Turizmi ve Elektronik Tatil Tasarım Site Uygulaması, Uluslararası Sosyal ve Ekonomik Bilimler Dergisi, 2 (2): 49-54.

Çıkın, A., Çeken, H. ve Uçar, M. (2009). Turizmin Tarım Sektörüne Etkisi, Agro-Turizm ve Ekonomik Sonuçları, Tarım Ekonomisi Dergisi, 15 (1): 1-8.

Çınar, Y. (2004). Çok Nitelikli Karar Verme ve Bankaların Mali Performanslarının Değerlendirilmesi Örneği. (Yayımlanmamış Yüksek Lisans Tezi). Ankara Üniversitesi Sosyal Bilimler Enstitüsü İşletme Anabilim Dalı, Ankara.

Doğanay, H. ve Coşkun, O. (2012). Tarım Coğrafyası. 2. Baskı. Erzurum: Pegem Akademi.

Douglas, N., Douglas, N. ve Derrett, R. (2001). Special Interest Tourism. Avustralya: John Wiley and Sons, Milton.
Efe, R. (1999). Güney Marmara Bölümü Batısında Toprak Oluşumunu Etkileyen Faktörler ve Toprakların Özellikleri, Türk Coğrafya Dergisi, 34: 193-209.

Efe, R. (2010). Biyocoğrafya. Bursa: MKM Yayıncılık.

Efe, R., Sönmez, S., Cürebal, İ. ve Soykan, A. (2008). Balıkesir'in Geoturizm Yöreleri: Marmara Geoturizm Yöresi Örneği, 3. Balıkesir Ulusal Turizm Kongresi, 17-19 Nisan 2008, Balikesir.

Flanigan, S., Blackstock, K. ve Hunter, C. (2014). Agritourism from the Perspective of Providers and Visitors: A Typology-Based Study, Tourism Management, 40: 394-405.

Fleischer, A. ve Tchetchik, A. (2005). Does Rural Tourism Benefit from Agriculture?, Tourism Management, 26 (4): 493-501.

Gıda Tarım ve Hayvancılık Bakanlığı Hatay İl Müdürlüğü. (2013). Brifing Dosyası Ocak 2013 (2012 yılsonu brifingi). Gıda Tarım ve Hayvancılık Bakanlığı Hatay İl Müdürlüğü, Hatay.

Gil Arroyo, C., Barbieri, C. ve Rozier Rich, S. (2013). Defining Agritourism: A Comparative Study of Stakeholders' Perceptions in Missouri and North Carolina, Tourism Management, 37: 39-47.

Gossling, S. ve Mattson, S. (2002). Farm Tourism in Sweden: Structure, Growth and Characteristics, Scandinavian Journal of Hospitality and Tourism, 2 (1): 17-30.

Gökalp, D. D. ve Yazgan, M. E. (2013). Kırsal Peyzaj Planlamada Agroturizm ve Agriturizm, KMÜ Sosyal ve Ekonomik Araştırmalar Dergisi, 15 (24): 25-29.

Güçlü, Y. (2010). Doğu Karadeniz Bölümü Kıyı Kuşağında İklim Konforu Şartlarının Kıyı Turizmi Yönünden İncelenmesi, Coğrafi Bilimler Dergisi, 8 (2): 111-136.

Gündüz, S. (2004). Ankara İli Kalecik İlçesinde Tarımsal Turizme Uygun Alanların Saptanması ve Tarımsal Turizm Modelinin Oluşturulması Üzerine Bir Araştırma. (Yayımlanmamış Doktora Tezi). Ankara Üniversitesi Fen Bilimleri Enstitüsü Peyzaj Mimarlı̆̆ 1 Anabilim Dalı, Ankara.

Henderson, J. C. (2009). Agro-tourism in Unlikely Destinations: A Study of Singapore, Managing Leisure, 14 (4): 258-268.

Herrera Catalino, A. ve Lizardo, M. (2004). Agriculture, Environmental Services and Agro-Tourism in the Dominican Republic, e-Journal of Agricultural and Development Economics, 1 (1): 87-11.

Hjalager, A. M. (1996). Agricultural Diversification into Tourism. lburism Management, 17 (2): 103-111.

Hurma, H., Kubaş, A. ve İnan, Ç. (2011). Trakya Bölgesindeki Tarımsal Üreticilerin Ek Gelir Olanakları: Tarım Turizmi. Uluslararası II. Trakya Bölgesi Kalkınma - Girişimcilik Sempozyumu, Bildiri Kitabı I (Editörler: Muharrem Öztel ve Hüseyin Burgazoğlu), Kırklareli Üniversitesi Yayınları: 2, İktisadi ve İdari Bilimler Fakültesi Yayınları: 1, 219-227.

Iakovidou, O., Emmanouilidou, M., Stavrakas, T., Simeonidou, P. ve Chrisostomidis, C. D. (2001). Trends of Tourism Market for Agro-Tourism, Anatolia: An International Journal of Tourism and Hospitality Research, 12 (2): 165-179.

Ilbery, B., Bowler, I.; Clarke, G.; Crockett, A. ve Shaw A. (1998). Farm-Based Tourism As An Alternative Farm Enterprise: A Case Study From The Northern Pennines, England, Regional Studies, 32 (4): 355-365. 
Irshad, H. (2010). Rural Tourism, An Overview, http://www1.agric.gov.ab.ca/\$Department/deptdocs.nsf/all/csi13476/\$FILE/ Rural-Tourism.pdf, Erişim tarihi: 4 Eylül 2011.

Karabati, S., Doğan, E., Pınar, M. ve Çelik, L. M. (2009). SocioEconomic Effects of Agri-Tourism on Local Communities in Turkey: The Case of Aglasun, International Journal of Hospitality \& Tourism Administration, 10 (2): 129-142.

Karanlık, S., Ağca, N. ve Yalçın, M. (2010). Spatial Distribution of Heavy Metals Content in Soils of Amik Plain (Hatay, Turkey), Environmental Monitoring and Assessment, 173 (14): 181-191.

Kaymaz, Ç. K. ve Özşahin, E. (2013). Hatay İlinin Potansiyel Eko Turizm Alanlarının Coğrafi Açıdan Değerlendirilmesi (Doğu Akdeniz). 2. Doğu Akdeniz Turizm Sempozyumu "Ekoturizm", 19 Nisan 2013 Bildiriler Kitabı, Editör: Murat İsmet Haseki, 161-179, Adana: Ofis Reklam Danışmanlık.

Kılıç, B. ve Kurnaz, A. (2010). Alternatif Turizm ve Ürün Çeşitliliği Oluşturmada Ekolojik Çiftlikler: Pastoral Vadi Örneği, İşletme Araştırmaları Dergisi, 2 (4): 39-56.

Kılıç, Ş. (2011). Agroecological Landuse Potential of Amik Plain, Turkey, Turkish Journal of Agriculture and Forestry, 35: 433-442.

Kılıç, Ş., Ağca, N., Karanlık, S., Şenol, S., Aydın, M., Yalçın, M., Çelik, İ., Evrendilek, F., Uygur, V., Doğan, K., Aslan, S. ve Çullu, M. A. (2008). Amik Ovasının Detaylı Toprak Etütleri, Verimlilik Çalışması ve Arazi Kullanım Planlaması. Mustafa Kemal Üniversitesi Bilimsel Araştırma Projeleri, Proje No: DPT2002K120480.

Kiper, T. ve Arslan, M. (2007). Safranbolu-Yörükköyü Tarımsal Turizm Potansiyelinin Kırsal Kalkınma Açısından Değerlendirilmesi, Süleyman Demirel Üniversitesi Orman Fakültesi Dergisi, 2: 145-158.

Kizos, T. ve Iosifides, T. (2007). The Contradictions of Agrotourism Development in Greece: Evidence from Three Case Studies, South European Society and Politics, 12 (1): 59-77.

Klein, C., Cardenas, D., Leung, Y. F. ve Sanders, S. (2007). Sustainable Farm Tourism: Understanding and Managing Environmental Impacts of Visitor Activities, 45 (2), http:// www.joe.org/joe/2007april/rb2.php, Erişim tarihi: 20 Ağustos 2011.

Koçman, A. (1993). Türkiye İklimi. İzmir: Ege Üniversitesi Edebiyat Fakültesi Yayınları No: 72.

Koday, Z., Kaymaz, Ç. K. ve Özşahin, E. (2013). Turizmin Doğal Çevre ile İlişkisine Bir Örnek: Camili (Macahel) Biyosfer Rezerv Alanı (Artvin, KD Türkiye), Coğrafyacılar Derneği Yillık Kongresi Bildiriler Kitabı: 19-21 Haziran 2013/Editörler: Ali Demirci, Yılmaz Arı, 828-837, Balıkesir: Coğrafyacllar Derneği.

Korkmaz, H. (2008). Antakya-Kahramanmaraş Graben Alanında Kurutulan Sulak Alanların (Amik Gölü, Emen Gölü ve Gâvur Gölü Bataklığı) Modellerinin Oluşturulması, Mustafa Kemal Üniversitesi Sosyal Bilimler Enstitüsü Dergisi, 5 (9): 19-37.

Korkmaz, H. (2009). Amik Ovası'nda Kurak Devre ile Buğday, Pamuk ve Mısır Tarımı Arasındaki İlişki, Mustafa Kemal Üniversitesi Sosyal Bilimler Enstitüsü Dergisi, 6 (11): 56-88.

Korkmaz, H. ve Gürbüz, M. (2008). Amik Gölü'nün Kültürel Ekolojisi, Marmara Coğrafya Dergisi, 17: 1-26.
Kozak, N., Kozak, M. A. ve Kozak, M. (2001). Genel Turizm, Illkeler-Kavramlar. 5. Baskı, Ankara: Detay Yayıncılık.

Loureiro, M. L. ve Jervell-Moxnes, A. (2004). Analyzing Farms' Participation Decisions in Agro-tourism Activities in Norway: Some Welfare Implications. Selected Paper Presented at the American Agricultural Economics Association Annual Meetings. Denver, Colorado.

McKenzie, N. ve Wysocki, A. (2002). Agritainment: A Viable Option for Florida Producers. IFAS Extension - Florida Üniversitesi.

Ndubisi, F. (2002). Ecological Planning-A Historical and Comparative Synthesis. Baltimore ve Londra: The Johns Hopkins Üniversitesi Yayınları.

Nickerson, N. P., Black, R. J. ve Mccool, S. F. (2001). Agritourism: Motivations Behind Farm/Ranch Business Diversification, Journal of Travel Research, 40 (1): 19-26.

Nilsson, P. A. (2002). Staying on Farms, An Ideological Background, Annals of Tourism Research, 29 (1): 7-24.

Olalı, H. ve Timur, A. (1988). Turizm Ekonomisi. İzmir: Ofis Ticaret Matbaacilık.

Ölgen, M. K. (2003). Coğrafi Bilgi Sistemleri Yardımıyla Turizm Amaçlı Çevresel Duyarlılığın Belirlenmesi. Ege Üniversitesi Coğrafya Bölümü Sempozyumları 2, Coğrafi Çevre Koruma ve Turizm Sempozyumu 16-18 Nisan 2003, İzmir: Ege Üniversitesi Edebiyat Fakültesi Yayınları.

Özçağlar, A., Somuncu, M., Bayar, R., Yılmaz, M., Yüceşahin, M. M., Yavan, N., Akpınar, N. ve Karadeniz, N. (2006). Çamlıhemşin İlçesinde Doğal ve Beşeri Kaynak Tespitine Bağlı Olarak Geliştirilen Arazi Kullanım Kararları, Ankara Üniversitesi Coğrafi Bilimler Dergisi, 4 (1): 1-27.

Özdede, A. (2012). Tarım Turizmi (Agro-Turizm). (Yayımlanmamış Doktora Tezi). Dokuz Eylül Üniversitesi Sosyal Bilimler Enstitüsü Turizm İşletmeciliği Anabilim Dalı Turizm İşletmeciliği Doktora Programı, İzmir.

Özgüç, N. (2007). Turizm Coğrafyası (Özellikler ve Bölgeler). 5. Bask1, İstanbul: Çantay Kitabevi.

Özşahin, E. ve Değerliyurt, M. (2012). Antakya-Serinyol (Hatay) Güzergâhındaki Alt Geçit Projesinin Uygulamalı Jeomorfolojik Açıdan Değerlendirilmesi. 1. Ulusal Karayolları ve Trafik Güvenliği Sempozyumu (6-8 Mayıs 2010), 2010 Karayolu Trafik Güvenliği Sempozyumu Seçilmiş Bildiriler (Derleyen: Bedrettin MURAT), 172-193, Ankara.

Özşahin, E. ve Kaymaz, Ç. K. (2014). Coğrafi Bir Değerlendirme: Amik Ovası (Hatay) Höyükleri, Uluslararası Çă̆lar Boyunca Hatay ve Çevresi Arkeolojisi Sempozyumu Bildirileri, Hatay: Mustafa Kemal Üniversitesi Yayınları, .. 27-40.

Pamir, H. (2009). Alalakh'dan Antiocheia'ya Hatay'da Kentleşme Süreci, Mustafa Kemal Üniversitesi Sosyal Bilimler Enstitüsü Dergisi, 6 (12): 258-288.

Plummerw, R., Spiers, A., Summer, R. ve Fitzgibbon, J. (2008). The Contributions of Stewardship to Managing AgroEcosystem Environments, Journal of Sustainable Agriculture, 31 (3): 55-84.

Przezborska, L. (2003). Relationships Between Rural Tourism and Agrarian Restructuring in A Transitional Economy: The Case of Poland. İçinde D. Hall, M. Mitchell, and L. Roberts (Editörler), New Directions in Rural Tourism (ss: 203-222). Aldershot: Ashgate. 
Saaty, T. L. (1980). The Analytic Hiearchy Process. New York, McGraw Hill.

Selvi, M. S. ve Demirer, D. (2012). Ekolojik Tatil Çiftliklerinin TATUTA Projesi Deneyimine İlişkin Örnek Olay İncelemesi, Anatolia: Turizm Araştırmaları Dergisi, 23 (2): 187-202.

Senes, G. ve Toccolini, A. (1998). Sustainable Land Use Planning in Protected Rural Areas in Italy, Landscape and Urban Planning, 41: 107-117.

Sharpley, R. ve Sharpley J. (1997). Rural Tourism An Introduction. Londra: International Thomson Business Press.

Sharpley, R. ve Vass, A. (2006). Tourism, Farming and Diversification: An Attitudinal Study, Tourism Management, 27 (5): 1040-1052.

Shaw, G. ve Williams, A. (2002). Critical Issues in Tourism: A Geographical Perspective. Blackwell Publishers, U.K.

Soykan, F. (1999). Doğal Çevre ve Kırsal Kültürle Bütünleşen Bir Turizm Türü: Kırsal Turizm, Anatolia Turizm Araştırmaları Dergisi, 10: 67-75.

Soykan, F. (2000). Turizm Coğrafyası ve Turizm Planlaması, Ege Coğrafya Dergisi, 11: 39-55.

Soykan, F. (2002). Kırsal Turizmin Sosyo-Ekonomik Etkileri ve Türkiye. Türkiye Dağları I. Ulusal Sempozyumu, 25-27 Haziran 2002, Orman Bakanlığı Araştırma Planlama ve Koordinasyon Kurulu Başkanlığı, Orman Bakanlığı Yayınlar1: 183, Ankara.

Soykan, F. (2003a). Kırsal Turizm ve Türkiye Turizmi için Önemi, Ege Coğrafya Dergisi, 12: 1-11.

Soykan, F. (2003b). Coğrafi Çevrenin Turizm Amaçlı Değerlendirilmesinde Turizm Potansiyelini Saptamanın Önemi. Ege Üniversitesi Coğrafya Bölümü Sempozyumları 2, Coğrafi Çevre Koruma ve Turizm Sempozyumu 16-18 Nisan 2003, İzmir: Ege Üniversitesi Edebiyat Fakültesi Yayınları.

Tarlak, Ş. (2007). Mumcular'da Kırsal Turizm Modeli. Dokuz Eylül Üniversitesi. Mimarlık Fakültesi Şehir ve Bölge Planlama Bölümü, Şehir Planlama Projesi VI Dersi Çalışması, İzmir.

Taş, B. (2009). Tarım Alanlarının Planlaması Sürecinde SWOT Analizi Kullanımına Bir Örnek: Sandıkı İlçesi, Coğrafi Bilimler Dergisi, 9 (2): 189-207.

Topay, M. (2003). Bartın Uluyayla Peyzaj Özelliklerinin Rekreasyon-Turizm Kullanımları Açısından Değerlendirilmesi Üzerinde Bir Araştırma. (Yayımlanmamış Doktora Tezi). Ankara Üniversitesi Fen Bilimleri Enstitüsü Peyzaj Mimarlığı Anabilim Dalı, Ankara.

Topay, M. (2013). Mapping of Thermal Comfort for Outdoor Recreation Planning Using GIS: The Case of Isparta Province (Turkey), Turkish Journal of Agriculture and Forestry, 37: 110-120.
Tozar, T. (2006). Doğal Kaynakların Sürdürülebilirliği İçin Geliştirilen Ekolojik Planlama Yöntemleri. (Yayımlanmamış Yüksek Lisans Tezi). Yıldız Teknik Üniversitesi Fen Bilimleri Enstitüsü, İstanbul.

Turoğlu, H. ve Özdemir, H. (2005). Bartın İlinin Ekoturizm Potansiyelinin Belirlenmesi, Doğu Coğrafya Dergisi, 10 (13) 97-116

Türkben, C., Gül, F. ve Uzar, Y. (2012). Türkiye'de Bağcılığın Tarım Turizmi (Agro-Turizm) İçinde Yeri ve Önemi, KMÜ Sosyal ve Ekonomik Araştırmalar Dergisi, 14 (23): 47-50.

Varnac1, F. (2008). Kurutulan Amik Gölünün Yöresel Ekosistem Üzerindeki Etkileri. (Yayımlanmamış Yüksek Lisans Tezi). Balıkesir Üniversitesi Sosyal Bilimler Enstitüsü Coğrafya Anabilim Dalı, Balıkesir.

Veeck, G., Che, D. ve Veeck, J. (2006). America's Changing Farmscape: A Study of Agricultural Tourism in Michigan, The Professional Geographer, 58 (3): 235-248.

Wacher, C. (2006). The Development of Agri-tourism on Organic Farms in New EU Countries-Poland, Estonia and Slovenia. Report of a Winston Churchill Travelling Fellowship 2006, Winston Churchill Memorial Trust.

Weaver, D. B. ve Fennell, D. A. (1997). The Vacation Farm Sector in Saskatchewan: A Profile of Operations, Tourism Management, 18 (6): 357-365.

Wicks, B. ve Merrett, C. (2003). Agritourism: An Economic Opportunity for Illinois, Rural Research Report, 14 (9), 1-8.

Woo, L. S. ve Yeon, N. S. (2006). Agro-Tourism As A Rural Development Strategy in Korea, Journal of Rural Development, 29 (6): 67-83.

Yang, Z., Cai, J. ve Sliuzas, R. (2010). Agro-Tourism Enterprises As A Form of Multi-Functional Urban Agriculture for Peri-Urban Development in China, Habitat International, 34: 374-385.

Yavuzaslanoğlu, E. ve Yavuz, M. (2012). Karaman'ın Tarım Turizmi Yönünden Potansiyeli, KMÜ Sosyal ve Ekonomik Araştırmalar Dergisi, 14 (22): 31-33.

Yener, K. A., Edens, C., Harrison, T. P., Verstraete, J. ve Wilkinson, T. (2000). The Amuq Valley Regional Project 19951998, American Journal of Archaelogy, 104: 163-220

Yener, K. A. (2005). The Amuq Valley Regional Projects, The Amuq Valley Regional Projects. Cilt 1: Surveys in the Plain of Antioch and Orontes Delta Türkiye, 1995-2002, Editörler: K. A. Yener, ss. 1-24, Oriental Enstitüsü Yayınları No: 131, Chicago.

Zor, M. (2000). Amik Ovası Tabanının Ortam Koșullarında Meydana Gelen Değişiklikler. (Yayımlanmamış Yüksek Lisans Tezi). Firat Üniversitesi Sosyal Bilimler Enstitüsü Coğrafya Anabilim Dalı, Elazığ. 